Article

\title{
Ion Release and Surface Characterization of Nanostructured Nitinol during Long-Term Testing
}

\author{
Elena O. Nasakina *, Maria A. Sudarchikova, Konstantin V. Sergienko, Sergey V. Konushkin and \\ Mikhail A. Sevost'yanov
}

Laboratory of Durability and Plasticity of Metal and Composite Materials and Nanomaterials, Institution of Russian Academy of Sciences, A.A. Baikov Institute of Metallurgy and Material Science RAS (IMET RAS), Leninsky Prospect 49, 119991 Moscow, Russia; bloodymaria@list.ru (M.A.S.); shulf@yandex.ru (K.V.S.); venev.55@mail.ru (S.V.K.); cmakp@mail.ru (M.A.S.)

* Correspondence: nacakina@mail.ru; Tel.: +7-985-966-5408

Received: 14 September 2019; Accepted: 28 October 2019; Published: 5 November 2019

\begin{abstract}
The corrosion resistance of nanostructured nitinol (NiTi) was investigated using long-term tests in solutions simulating physiological fluids at static conditions, reflecting the material structure and metal concentration in the solutions. Mechanical polishing reduced the ion release by a factor of two to three, whereas annealing deteriorated the corrosion resistance. The depassivation and repassivation of nitinol surfaces were considered. We found that nanostructured nitinol might increase the corrosion leaching of titanium into solutions, although the nickel release decreased. Metal dissolution did not occur in the alkaline environment or artificial plasma. A Ni-free surface with a protective $25 \mathrm{~nm}$-thick titanium oxide film resulted from soaking mechanically treated samples of the NiTi wire in a saline solution for two years under static conditions. Hence, the medical application of nanostructured NiTi, such as for the production of medical devices and implants such as stents, shows potential compared with microstructured NiTi.
\end{abstract}

Keywords: alloy; nickel; titanium; pitting corrosion; repassivation

\section{Introduction}

Nitinol (NiTi) is an alloy characterized by high mechanical biocompatibility, including super elasticity and compliance with the delay law, all of which enable integration with living tissue [1-6]. NiTi also has shape memory effects that allow its application in the development of intelligent systems with programmable shapes.

However, the highly toxic Ni content of the alloy is capable of causing DNA damage, inflammation, formation of $\mathrm{O}$ radicals, tissue death around NiTi implants, tumor growth, allergies, and genetic mutations, and this has limited its application in medical devices [7-12]. No exact information is currently available about the tolerance limit of $\mathrm{Ni}$ content in an in vivo environment. However, concentrations of nickel ions significantly suppressed cell proliferation even at $25 \mu \mathrm{M}$ after three days [7]. Growth inhibition of smooth muscle cells became significant when the nickel concentration was above $9 \mathrm{ppm}$ [8]. A threshold value of $30 \mathrm{ppm}$ was needed to trigger a cytotoxic response during in vitro experiments [9]. After seven days, necrosis spread $1 \mathrm{~mm}$ around the implant and nickel concentrations reached $48 \mu \mathrm{g} / \mathrm{g}$ near the implants [10]. The Ni dispersion area was consistent with the inflammatory area and the degree of tissue damage was closely related to the dissolved $\mathrm{Ni}$ concentration [11]. The possibility of destruction by corrosion under variable dynamic loads limits the lifetime of devices fabricated from the alloy.

The electrochemical properties of NiTi are reported to be similar to those of corrosion-resistant Ti. However, various researchers have noted that the electrochemical properties of NiTi in medical 
applications range from poor to good [1,13-23]. Widely varying concentrations (1-100 mg/L) and durations (hours to months) of Ni ion release have also been reported for microstructured NiTi in physiological or saline environments [22-33]. Therefore, both positive and negative results have been reported in the above studies, as well as in vivo and in vitro biological studies of nitinol [1,8,22,32-41], leading to ambiguous and conflicting conclusions regarding its utility. However, an observation that has been common to all NiTi investigations is that the surface conditions of the alloy strongly affect its resistance to dissolution. Specifically, the corrosion resistance of the material has been determined to be better when the surface oxide layer is less damaged and contaminated.

Heat treatment of nitinol at $300-1000{ }^{\circ} \mathrm{C}$ is required to stabilize the relevant mechanical properties of the material and to shape a product; however, this may also adversely affect the corrosion resistance $[16,19,26,42-46]$. Heating causes the formation of a thick and uneven surface layer consisting of a mixture of $\mathrm{Ni}$ and $\mathrm{Ti}$ oxides. This oxide layer is extremely unstable under applied loads and contributes to the diffusion of nickel into the environment, which indicates the necessity of additional processing.

A wide range of methods are available for facilitating the formation of an improved homogeneous and naturally occurring titanium oxide surface layer with a minimum Ni content and a film thickness of up to several hundred nanometers. These methods include chemical passivation, anodizing, laser oxidation, oxidation in boiling water and autoclaves, electropolishing, and deposition [16,18,19,25-27,29,42-78]. However, these methods cause problems such as reduced biocompatibility, reduced corrosion resistance under cyclic thermal and mechanical loads, and mechanical property degradation $[17,28,41,47-50,56]$. Some of these treatment methods are not applicable to products with complex configurations, are expensive, or may induce heterogenous residual stress fields [16]. Mechanical surface treatment does not remove Ni from the surface and does not significantly increase the corrosion resistance and biocompatibility of the material $[16,26,27,45]$.

Although improvements to the mechanical properties of NiTi are not needed, its corrosion resistance and biocompatibility urgently require enhancement. Managing the properties of NiTi and NiTi-based alloys to enable their processing and use in the fabrication of medical implants and equipment has been extremely difficult. While NiTi has been successfully applied in medical devices such as stents, the properties of prostheses created from the material require improvement. The creation of nanostructures in the material shows promise for addressing some of the challenges. In this study, we investigated the corrosion resistance and related surface morphology and surface composition changes of nanostructured NiTi under static conditions through long-term testing in different solutions.

\section{Materials and Methods}

Nanostructured nitinol wires (IMET RAS; Moscow, Russia) were investigated. They were obtained according to the scheme given below. We subject $56 \mathrm{wt} \% \mathrm{Ni}-44 \mathrm{wt} \% \mathrm{Ti}$ mixture to multistage re-melting in a vacuum furnace under an argon atmosphere. Ingots weighing less than $400 \mathrm{~g}$ were subjected to homogeneous annealing at $750-1000{ }^{\circ} \mathrm{C}$ for $10 \mathrm{~h}$ to stabilize the grain structure. After, the ingots were sequentially converted by stepwise hot rolling at $700-750{ }^{\circ} \mathrm{C}$ and rotary forging at $750-1000{ }^{\circ} \mathrm{C}$ into bars of up to $4 \mathrm{~mm}$ in diameter. From the bars, wires, $0.4-0.28 \mathrm{~mm}$ in diameter, were obtained by multiple stepwise hot drawing through synthetic diamond dies. Between all the steps, intermediate heat processing was also performed.

The surface of the samples was subsequently mechanically treated along the axis of the samples using sandpaper (abrasive grain sizes from 180 to 1000 grit) and diamond paste ( $3 \mu \mathrm{m}$ followed by $1 \mu \mathrm{m}$ ) to a mirror finish. This process resulted in a reduction of the sample diameter by up to $10 \mu \mathrm{m}$ compared to the as-received samples (after production). The as-received and mechanically treated wires were annealed at $450{ }^{\circ} \mathrm{C}$ for $15 \mathrm{~min}$ in air using a muffle furnace (LOIP LF series, model 7/13-G2, Moscow, Russia). The wire diameter was unchanged during annealing. 
The characteristic grain type and size of the wire samples were determined by transmission electron microscopy (TEM; TECNAI 12, FEI Company, Hillsboro, Oregon USA). The samples were prepared using an ion etching apparatus (Gatan 691, Gatan Inc., Pleasanton, CA, USA).

The phase occurrence of the samples was determined by X-ray diffraction (XRD; Ultima IV, Rigaku Co., Woodlands, TX, USA) using $\mathrm{Cu} \mathrm{K} \alpha$ radiation with a graphite monochromator, vertical goniometer, and rapid semiconductor detector (D/teX). The Bragg-Brentano method was employed. Phase analysis was conducted using the PDXL program complex (Rigaku Co., Woodlands, TX, USA) and ICDD database.

The morphology and sub-surface elemental composition of the samples were investigated using scanning electron microscopy (SEM; TESCAN VEGA II SBU, TESCAN, Brno, Czech Republic) with an attached energy-dispersive X-ray spectroscopy (EDS) module (INCA Energy). Auger electron spectroscopy (JAMP-9500F, JEOL Co., Tokyo, Japan) combined with ion beam etching during argon bombardment at an angle of $30^{\circ}$ was also employed. All nitinol samples were ultrasonically cleaned in alcohol immediately before analysis, except for samples immersed in solutions. The latter were not cleaned to prevent the washing off of any possible sediment.

For microstructural analysis, the samples of nanostructured nitinol wires used for the actual tests were prepared by 2-3 min of pre-etching using a mixture of $\mathrm{HF}(1 \mathrm{~mL}), \mathrm{HNO}_{3}(2 \mathrm{~mL})$, and water $(47 \mathrm{~mL})$, followed by rinsing multiple times with distilled water and then air drying. A metallographic optical microscope (Axiovert 40 MAT, Carl Zeiss, Oberkochen, Germany) with digital image processing capability was used to image the samples.

Since $\mathrm{pH}$ values ranging from $\sim 1$ to 9 are found in the human body (for example, $\mathrm{pH}=1.05$ in a duodenal ulcer, 1.53-1.67 in gastric acid, 3.8-4 close to the intestinal canal wall, 7.34-7.43 in blood; and 8.5-9 in the large intestine), we decided to conduct tests at several $\mathrm{pH}$ values. We used seven solutions: four standard buffer solutions (prepared from pre-made buffer kits (Merck) with $\mathrm{pH}$ values of 1.68-4.01, 9.18), $\mathrm{HCl}$ (aq., $0.0275 \mathrm{M}, \mathrm{pH} 1.56$ ), $\mathrm{NaCl}$ (aq., 0.9 wt \%, $\mathrm{pH} 6.3$ ), and artificial plasma (pH 7.36) (Table 1) [16,17,20,23,26,27,29,30,46,49,78].

Table 1. $\mathrm{pH}$ and composition of the solutions used for immersion tests.

\begin{tabular}{|c|c|c|}
\hline Solution Number & $\mathrm{pH}$ & Composition \\
\hline 1 & 1.68 & Potassium tetraoxalate $\mathrm{KH}_{3} \mathrm{C}_{4} \mathrm{O}_{8} \cdot 2 \mathrm{H}_{2} \mathrm{O}, 0.05 \mathrm{M}$ \\
\hline 2 & 3.56 & Acid potassium tartrate $\mathrm{C}_{4} \mathrm{H}_{5} \mathrm{O}_{6} \mathrm{~K}, 0.025 \mathrm{M}$ \\
\hline 3 & 4.01 & Acid potassium phthalate $\mathrm{C}_{8} \mathrm{H}_{5} \mathrm{O}_{4} \mathrm{~K}, 0.05 \mathrm{M}$ \\
\hline 4 & 6.31 & Sodium chloride $\mathrm{NaCl}, 0.9 \mathrm{wt} \%$ \\
\hline 5 & 9.18 & Acid sodium tetraborate $\mathrm{Na}_{2} \mathrm{~B}_{4} \mathrm{O}_{7} \cdot 10 \mathrm{H}_{2} \mathrm{O}, 0.05 \mathrm{M}$ \\
\hline 6 & 7.36 & $\begin{array}{c}\text { Artificial plasma: } \mathrm{NaCl}(92.3 \mathrm{mM}), \mathrm{NaHCO}_{3}(26.3 \mathrm{mM}), \mathrm{K}_{2} \mathrm{HPO}_{4}(0.9 \mathrm{mM}), \\
\mathrm{KCl}(2.7 \mathrm{mM}), \mathrm{NaH}_{2} \mathrm{PO}_{4}(0.22 \mathrm{mM}), \mathrm{CaCl}_{2}(2.5 \mathrm{mM}), \mathrm{MgSO}_{4} \cdot 7 \mathrm{H}_{2} \mathrm{O} \\
(0.82 \mathrm{mM}), \mathrm{Na}_{2} \mathrm{SO}_{4}(1.48 \mathrm{mM}), \text { d-glucose } \mathrm{C}_{6} \mathrm{H}_{12} \mathrm{O}_{6}(5.55 \mathrm{mM}) \\
{[16,17,20,23,26,27,29,30,46,49,78]}\end{array}$ \\
\hline 7 & 1.56 & $\mathrm{HCl}$ (aq.), $0.0275 \mathrm{M}$ \\
\hline
\end{tabular}

Four types of samples of the nanostructured NiTi wires corresponding to four different states during the treatment-as-received (Sample 1), after annealing (Sample 2, at $450{ }^{\circ} \mathrm{C}$ for $15 \mathrm{~min}$ ), after mechanical treatment (Sample 3, using sandpaper with abrasive grain sizes from 180 to 1000 grit and diamond paste), and after mechanical treatment and subsequent annealing (Sample 4)-were used for the tests, with each wire weighing $32.6 \mathrm{~g}$. Wire samples of each type were placed in $100 \mathrm{~mL}$ of the different test solutions contained in flat-bottomed flasks composed of thermal laboratory glass (for the neutral and acidic solutions) and polypropylene (for the alkaline solution). The flasks were corked tightly and stored in the dark in intervals between sampling (Table 2). The solutions were analyzed by inductively coupled plasma atomic emission spectroscopy (ICP-AES; ULTIMA 2, HORIBA Jobin Yvon, Kyoto, Japan). 
Table 2. Metal concentrations in various solutions measured by inductively coupled plasma atomic emission spectroscopy (ICP-AES) for various immersion times and samples types.

\begin{tabular}{|c|c|c|c|c|c|c|c|c|c|}
\hline \multirow{3}{*}{$\begin{array}{l}\text { Solution } \\
\text { Number }\end{array}$} & \multirow{3}{*}{$\begin{array}{l}\text { Time } \\
\text { (Days) }\end{array}$} & \multicolumn{8}{|c|}{ Ion Concentration in Solution $(\mathrm{mg} / \mathrm{L})$} \\
\hline & & \multicolumn{2}{|c|}{$\begin{array}{l}\text { As-Received } \\
\text { Sample (1) }\end{array}$} & \multicolumn{2}{|c|}{$\begin{array}{c}\text { Annealed Sample } \\
\text { (2) }\end{array}$} & \multicolumn{2}{|c|}{$\begin{array}{c}\text { Mechanically } \\
\text { Treated Sample (3) }\end{array}$} & \multicolumn{2}{|c|}{$\begin{array}{c}\text { Annealed } \\
\text { Mechanically } \\
\text { Treated Sample (4) }\end{array}$} \\
\hline & & $\mathrm{Ti}$ & $\mathbf{N i}$ & $\mathrm{Ti}$ & $\mathrm{Ni}$ & $\mathrm{Ti}$ & $\mathbf{N i}$ & Ti & $\mathbf{N i}$ \\
\hline \multirow{8}{*}{1} & 0 & 0.00 & 0.00 & 0.00 & 0.00 & 0.000 & 0.000 & 0.000 & 0.000 \\
\hline & 10 & 1.30 & 2.13 & 4.00 & 6.20 & 0.470 & 0.710 & 0.317 & 0.245 \\
\hline & 25 & 1.90 & 2.97 & 6.50 & 9.00 & 0.640 & 0.940 & 0.467 & 0.784 \\
\hline & 45 & 2.30 & 3.67 & 9.08 & 9.97 & 0.750 & 1.150 & 0.556 & 0.958 \\
\hline & 60 & 3.05 & 4.16 & 9.81 & 10.44 & 0.810 & 1.250 & 0.614 & 1.087 \\
\hline & 75 & 3.14 & 4.26 & 9.86 & 10.55 & 0.860 & 1.300 & 0.656 & 1.182 \\
\hline & 287 & 3.15 & 4.29 & 10.01 & 10.70 & 1.070 & 1.550 & 1.284 & 1.860 \\
\hline & 754 & 9.60 & 13.39 & 20.70 & 24.60 & 3.340 & 4.550 & 4.559 & 5.898 \\
\hline \multirow{8}{*}{2} & 0 & 0.00 & 0.00 & 0.00 & 0.00 & 0.00 & 0.00 & 0.00 & 0.00 \\
\hline & 10 & - & 0.05 & - & 0.10 & - & 0.03 & - & 0.010 \\
\hline & 25 & - & 0.18 & - & 0.40 & - & 0.07 & - & 0.058 \\
\hline & 45 & - & 0.38 & 0.08 & 0.61 & - & 0.11 & - & 0.092 \\
\hline & 60 & 0.04 & 0.44 & 0.09 & 0.67 & - & 0.13 & - & 0.113 \\
\hline & 75 & 0.06 & 0.47 & 0.09 & 0.87 & - & 0.14 & - & 0.127 \\
\hline & 287 & 0.12 & 1.05 & 0.16 & 1.59 & - & 0.19 & - & 0.228 \\
\hline & 754 & 0.32 & 1.34 & 0.48 & 2.19 & 0.09 & 0.32 & 0.11 & 0.415 \\
\hline \multirow{8}{*}{3} & 0 & 0.00 & 0.00 & 0.00 & 0.00 & 0.00 & 0.00 & 0.00 & 0.00 \\
\hline & 10 & - & 0.03 & - & 0.04 & - & 0.01 & - & 0.003 \\
\hline & 25 & - & 0.06 & - & 0.07 & - & 0.02 & - & 0.017 \\
\hline & 45 & - & 0.07 & - & 0.14 & - & 0.02 & - & 0.017 \\
\hline & 60 & - & 0.09 & - & 0.14 & - & 0.03 & - & 0.026 \\
\hline & 75 & - & 0.10 & - & 0.18 & - & 0.03 & - & 0.027 \\
\hline & 287 & - & 0.41 & - & 0.57 & - & 0.10 & - & 0.120 \\
\hline & 754 & 0.01 & 0.50 & 0.01 & 0.63 & - & 0.14 & - & 0.181 \\
\hline \multirow{8}{*}{4} & 0 & 0.00 & 0.00 & 0.00 & 0.00 & 0.00 & 0.00 & 0.00 & 0.00 \\
\hline & 10 & - & 0.50 & 0.01 & 0.88 & - & 0.04 & - & 0.014 \\
\hline & 25 & - & 0.76 & 0.05 & 1.33 & - & 0.12 & - & 0.100 \\
\hline & 45 & 0.01 & 0.94 & 0.09 & 1.55 & - & 0.15 & - & 0.125 \\
\hline & 60 & 0.03 & 0.95 & 0.10 & 1.56 & - & 0.17 & - & 0.148 \\
\hline & 75 & 0.04 & 0.97 & 0.12 & 1.59 & - & 0.19 & - & 0.173 \\
\hline & 287 & 0.08 & 1.20 & 0.17 & 2.08 & - & 0.24 & - & 0.288 \\
\hline & 764 & 0.12 & 1.28 & 0.19 & 2.17 & - & 0.39 & - & 0.506 \\
\hline \multirow{2}{*}{7} & 0 & 0.00 & 0.00 & 0.00 & 0.00 & 0.00 & 0.00 & 0.00 & 0.00 \\
\hline & 10 & 0.515 & 1.94 & no & no & no & no & no & no \\
\hline
\end{tabular}

Note: -, a concentration less than $0.0066 \mathrm{mg} / \mathrm{L} ;$ no, no data.

\section{Results}

\subsection{Structure Analysis Before Corrosion}

The bright- and dark-field TEM images of the nanostructured NiTi wires (Figure 1) showed that the alloy grains occurred as nanofibers 30-70 $\mathrm{nm}$ in diameter and several micrometers long, with the grains extending along the wire axis. The microdiffraction, EDS, XRD, and microstructural analyses revealed that the main component of $\mathrm{NiTi}$ was a B2-phase $\mathrm{TiNi}$, with flecks of $\mathrm{Ti}_{2} \mathrm{Ni}$ intermetallic compounds [79]. The composition was found to be unchanged by the treatment processes. 


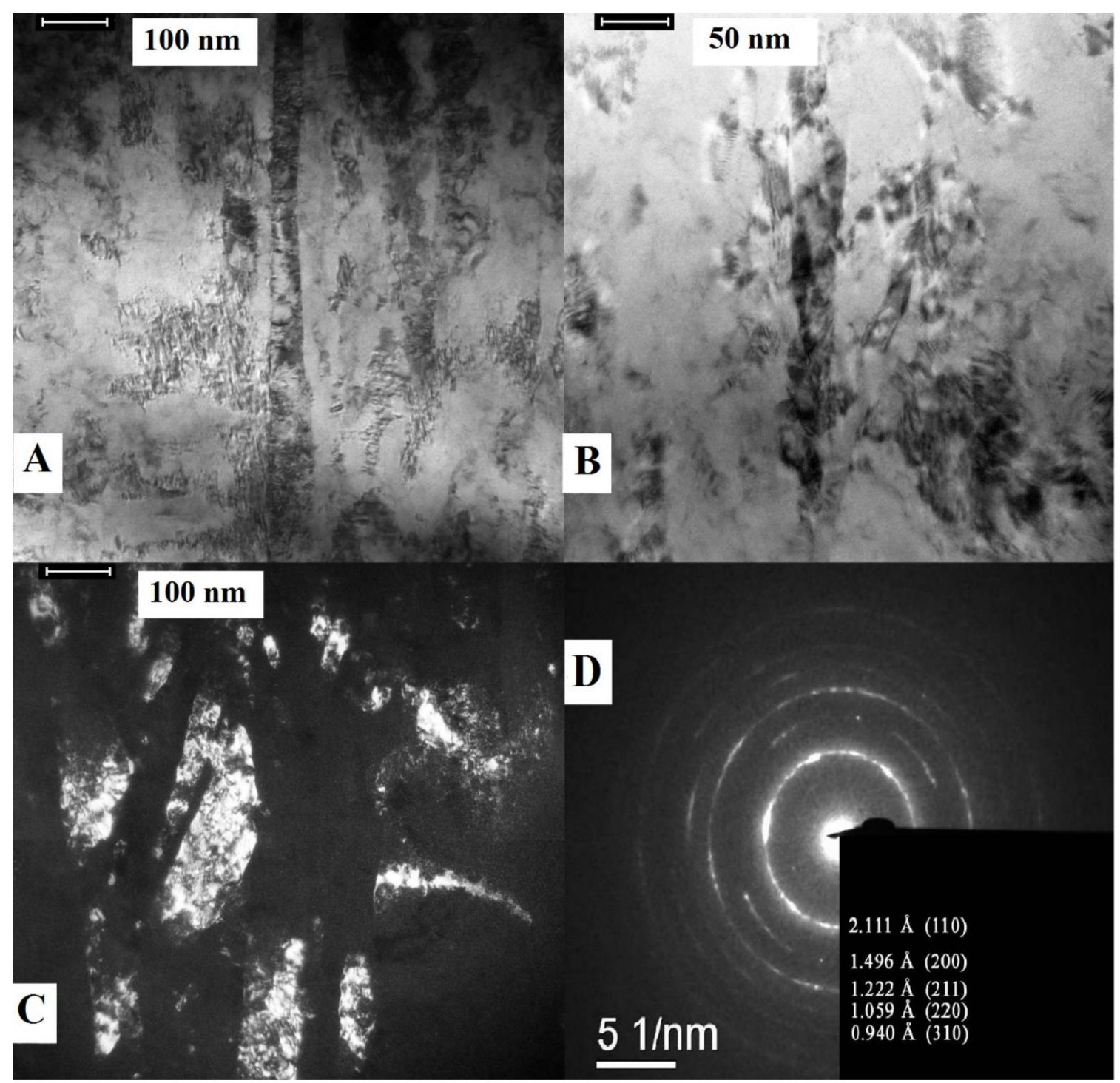

Figure 1. (A,B) Bright-field and (C) dark-field TEM images of the grain structure and (D) microdiffraction pattern of the nitinol wire before treatments. Bright-field images illustrate coaxial elongated grains; dark-field image illustrates more randomly spaced grains and its etched fragments.

The SEM images in Figure 2A show that the surface of the NiTi wires before treatment (as-received) was non-uniform, with the presence of light and dark areas of varying contrast, as well as obvious roughness and drawing defects, including fluted reliefs along the drawing axis and dimples caused by the press of solid particles into the surface. After annealing (Figure 2B), the surface remained mostly the same, the only difference being the presence of a higher proportion of bright spots. After mechanical treatment (Figure 2C), almost all the defects and roughness were removed, with no spots observed. Only the machining marks were present, which existed in the form of grooves with a depth and width of $1 \mu \mathrm{m}$. Subsequent annealing (Figure 2D) smoothed the surface. 


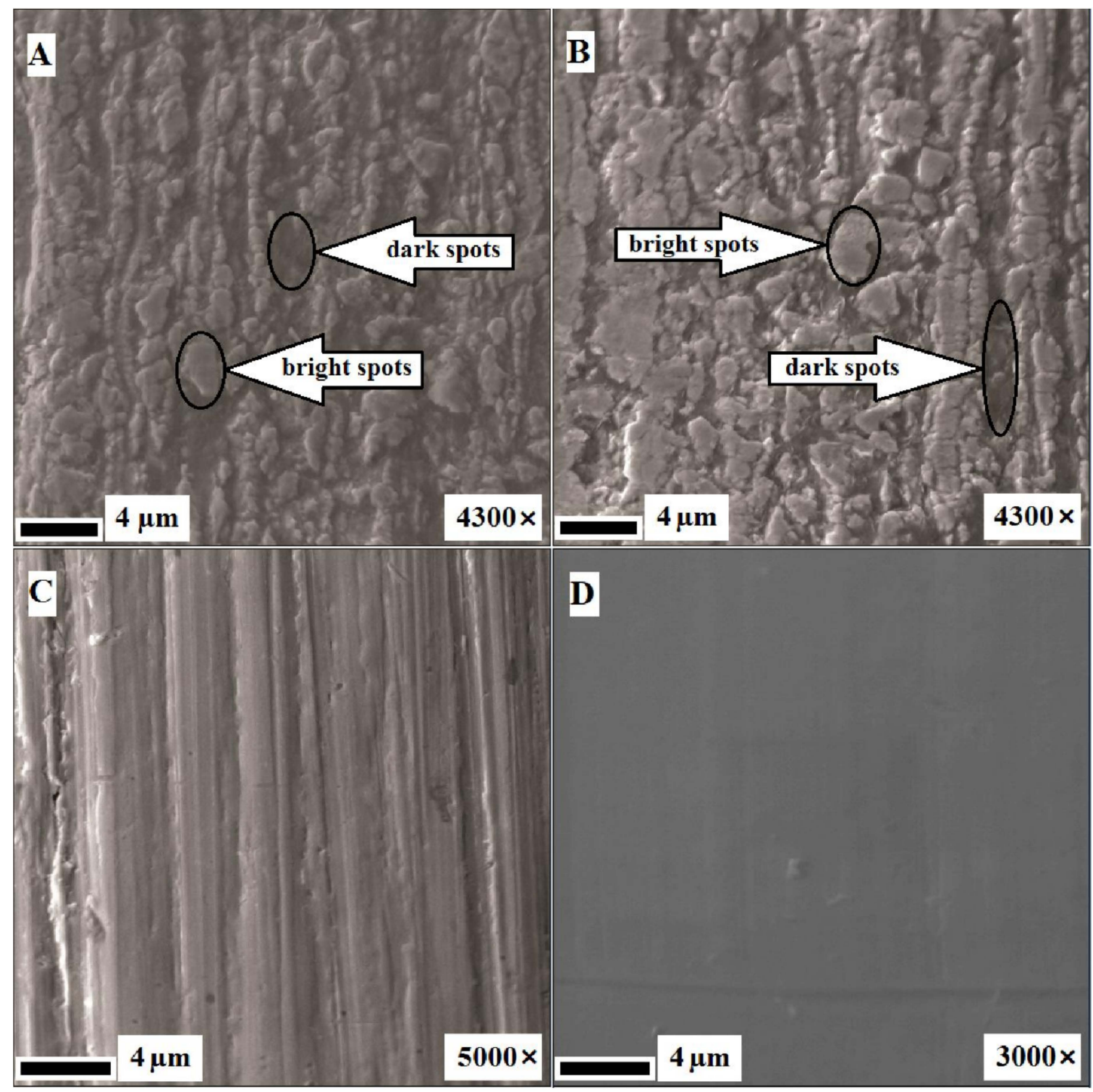

Figure 2. SEM images of the NiTi wire surface before immersion testing: (A) as-received (before processing); (B) after annealing at $450{ }^{\circ} \mathrm{C}$ for $15 \mathrm{~min}$; (C) after mechanical treatment to a mirror finish in the direction of the long axis of the samples using sandpaper (abrasive grain sizes from 180 to 1000 grit) and diamond paste $(3 \mu \mathrm{m}$ followed by $1 \mu \mathrm{m})$; and (D) mechanically treated and annealed sample. "Dark spots" and "bright spots" indicate different surface areas for additional composition analysis.

The bright and dark spots on the surface had different compositions, as indicated by the Auger electron spectroscopy results (Figure 3A,B). High concentrations of titanium oxide were observed in the bright spots (Figure 3A), whereas the dark spots were rich in carbon (Figure 3B). Both regions were $\sim 3 \mu \mathrm{m}$ thick and did not overlap. The annealing slightly increased the proportion of the surface oxide (Figure 2A,B). The composition of the mechanically treated surface was uniform (Figure 3C); the wire was covered by an oxide layer less than $10 \mathrm{~nm}$ thick. Subsequent annealing contributed (Figure 3D) to the formation of an oxide-nitride layer up to 80-150 nm deep. Nickel was not completely removed from both surfaces. 

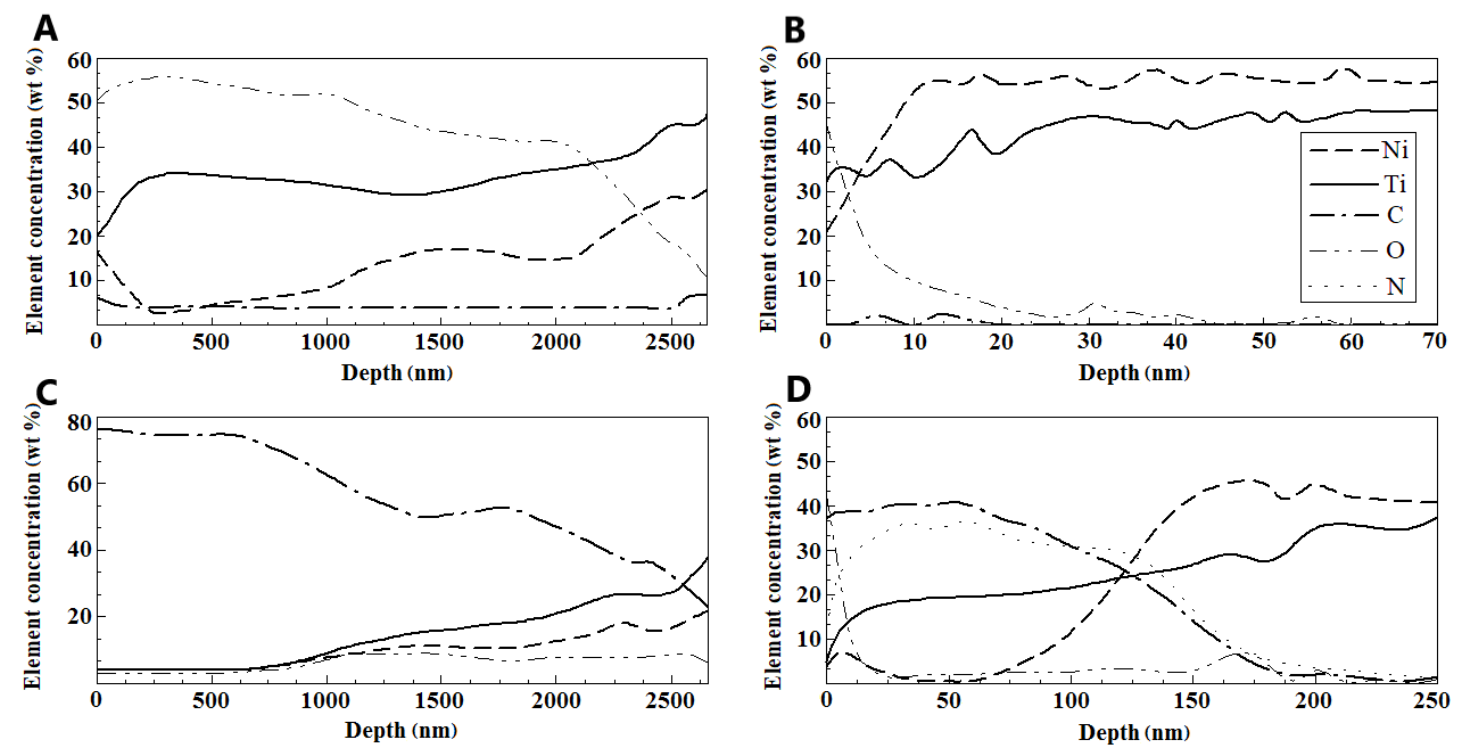

Figure 3. NiTi wire surface composition according to Auger electron spectroscopy before immersion tests: elemental depth profiles of (A) bright region (identified in Figure 2A,B) and (B) dark region (identified in Figure 2A,B) of the as-received sample and the sample annealed at $450{ }^{\circ} \mathrm{C}$ for $15 \mathrm{~min}$; surfaces of samples (C) mechanically treated using sandpaper (abrasive grain sizes from 180 to 1000 grit) and diamond paste $(3 \mu \mathrm{m}$ followed by $1 \mu \mathrm{m})$ and (D) mechanically treated and annealed.

\subsection{Surface Analysis After Corrosion}

The results of the surface SEM investigations showed that the annealed samples suffered the greatest corrosion damage after exposure to the different solutions (Figure 4). The least damaged samples were those that were mechanically treated (both annealed and not). The non-uniform surface corrosion resulted in the formation of deep pores (pitting). The SEM images suggested that the pitting corrosion damage was due to the drawing defects. 


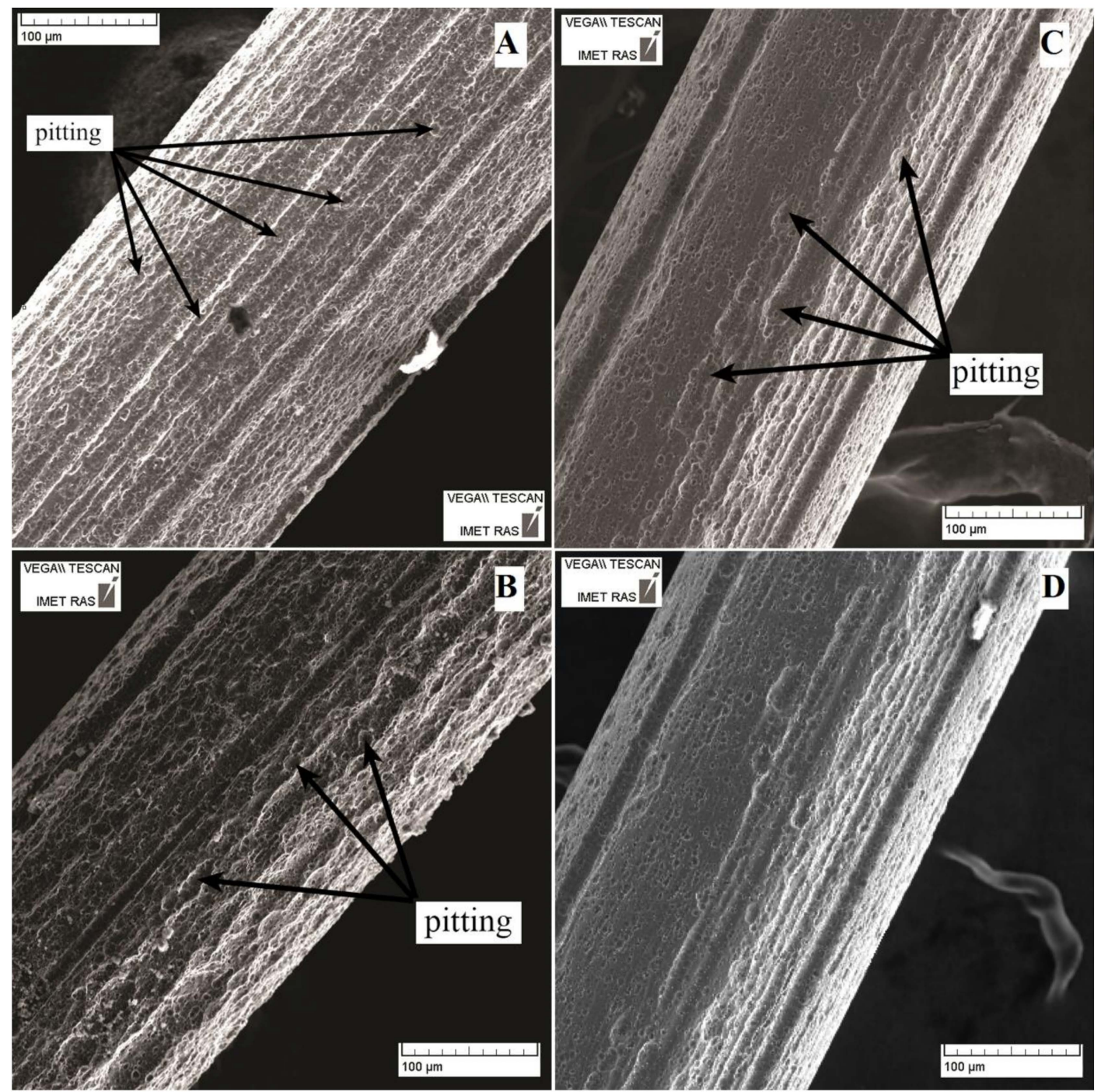

Figure 4. SEM image of the NiTi wire surface after two years of immersion testing in a buffer solution at pH 1.68 (Solution 1, Table 1): (A) as-received sample; (B) sample annealed at $450{ }^{\circ} \mathrm{C}$ for $15 \mathrm{~min}$; (C) sample mechanically treated in the direction of the long axis using diamond paste $(3 \mu \mathrm{m}$ followed by $1 \mu \mathrm{m}$ ) sample; and (D) sample mechanically treated and annealed.

Visual inspection after two years of storage (Figures 4A and 5; Table 3) suggested that the strongest corrosion occurred in the $\mathrm{pH} 1.68$ solution. Traces of corrosion in the form of loosening surfaces were observed in the NiTi wire samples exposed to the weakly acidic solution of pH 3.56 (Figure 5A; Table 3). No surface damage was observed in the samples exposed to the $\mathrm{pH} 4.01$ solution, although organic sediments partially covered the samples (Figure 5B; Table 3). In NaCl (Figure 5C; Table 3), the wire samples were covered by a homogeneous surface layer that was smoother than the surface of the as-received samples, and no evidence of pitting was observed. We observed the same for the wire samples exposed to the artificial plasma. We suggest that this layer was produced by repassivation of the damaged surface. No changes were observed in the diameter and surface structure of the wire samples exposed to the alkaline solution (Figure 5D; Table 3). No release of metallic ions was observed from the NiTi wire samples immersed in the $\mathrm{pH} 9.18$ solution, as substantiated by the unchanged appearance of the samples after the immersion. 

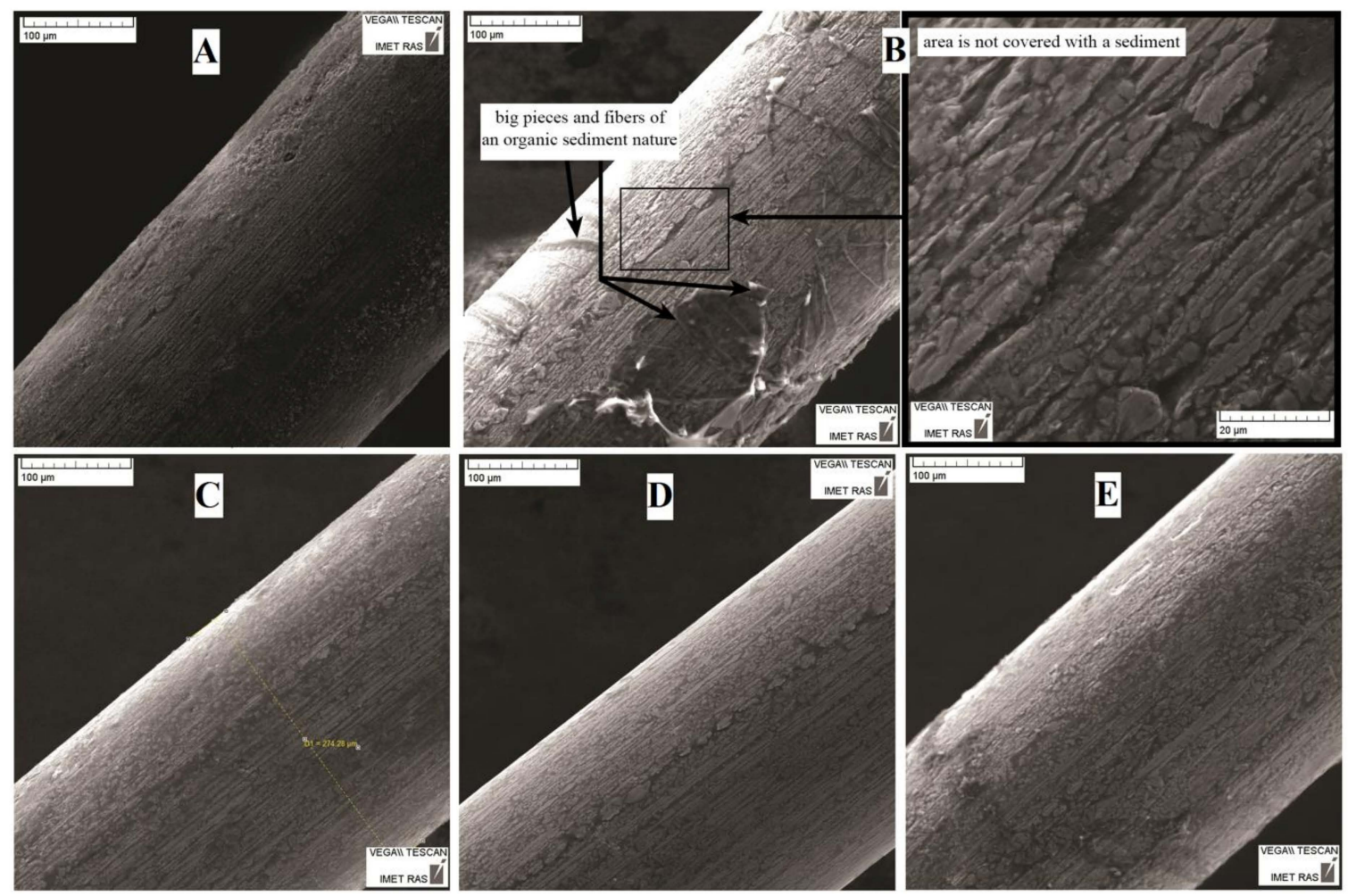

Figure 5. SEM images of the as-received NiTi sample surface after two years of immersion in various solutions: (A) buffer at $\mathrm{pH} 3.56$ (Solution 2; Table 1); (B) buffer at pH 4.01 (Solution 3, Table 1); (C) $0.9 \mathrm{wt} \% \mathrm{NaCl}$ (Solution 4, Table 1); (D) pH 9.18 (Solution 5, Table 1); and (E) HCl (pH 1.56).

Table 3. Diameters of each type of NiTi wire sample before and after immersion for two years in solutions with various $\mathrm{pH}$ values.

\begin{tabular}{cccc}
\hline $\begin{array}{c}\text { Diameter Before } \\
\text { Immersion }(\mu \mathrm{m})\end{array}$ & $\begin{array}{c}\text { Diameter After } \\
\text { Immersion }(\boldsymbol{\mu m})\end{array}$ & Sample & pH \\
\hline 280.00 & 253.74 & As-received & 1.68 \\
280.00 & 275.59 & As-received & 3.56 \\
280.00 & 277.14 & As-received & 4.01 \\
280.00 & 275.16 & As-received & 6.31 \\
280.00 & 280.00 & As-received & 9.18 \\
280.00 & 252.46 & Annealed & 1.68 \\
270.00 & 257.00 & Mechanically treated & 1.68 \\
280.00 & 270.03 & As-received & $1.5(\mathrm{HCl})$ \\
\hline
\end{tabular}

The surface compositions of both the as-received and annealed TiNi wire samples were observed to be unchanged by the long-term exposure to the different solutions. The samples still contained the alternating dark $\mathrm{C}$-containing areas with low $\mathrm{Ni}$ contents and light areas of titanium oxide with $\mathrm{Ni}$ inclusions (Figure 6). The auger electron spectroscopy results showed the depths of these areas to be greater than $1 \mu \mathrm{m}$. However, long-term immersion in a Cl-containing solution increased the oxide proportion on the surface. This is consistent with previously reported findings $[14,20,23,24,27,33]$. 


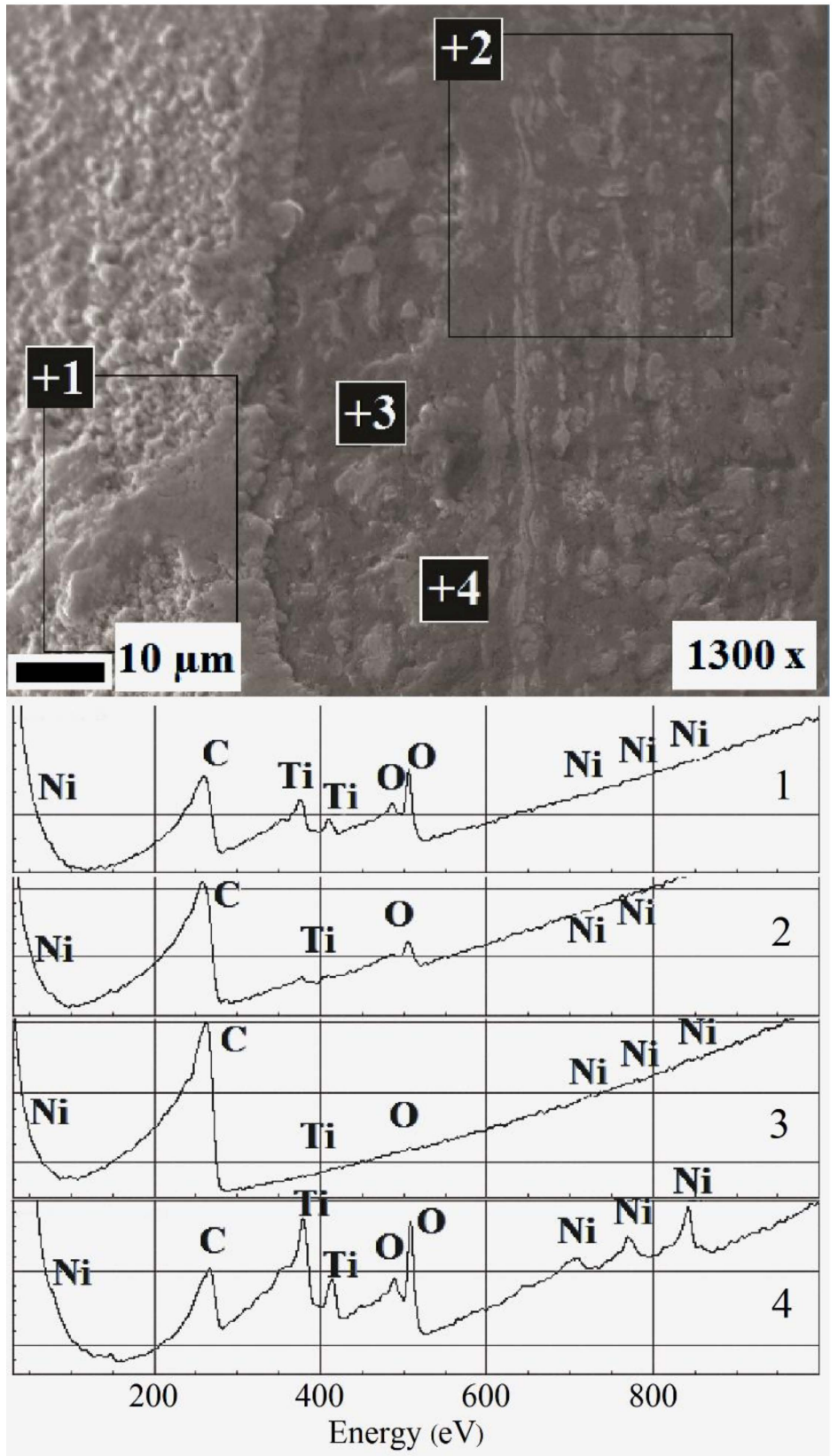

Figure 6. Surface structure of as-received nitinol after immersion in $0.9 \mathrm{wt} \% \mathrm{NaCl}$ solution (Solution 4 , Table 1) for two years. The Auger electron spectra (lower) were collected for the corresponding surface analysis areas (upper).

The surfaces of the mechanically treated samples after immersion for two years are shown in Figures $4 \mathrm{C}$ and 7. Pitting was only observed in the $\mathrm{pH} 1.68$ buffer solution. The surface oxide layer of the mechanically treated samples was found to extend to a maximum depth of $\sim 25 \mathrm{~nm}$ after immersion in the neutral solutions (Table 4). The relative proportions of the bonded and elemental forms of Ti in the samples immersed in $\mathrm{NaCl}$ solution were determined from the Auger data, which also revealed that no elemental Ti was observed until a depth of $17 \mathrm{~nm}$ (Figure 8). No Ni was observed on the corroded surface of the present samples immersed in $\mathrm{NaCl}$. The carbon concentration in the surface layer was observed to decrease sharply from a high level on the surface to zero at $\sim 15 \mathrm{~nm}$. This suggests mechanically induced surface contamination. 


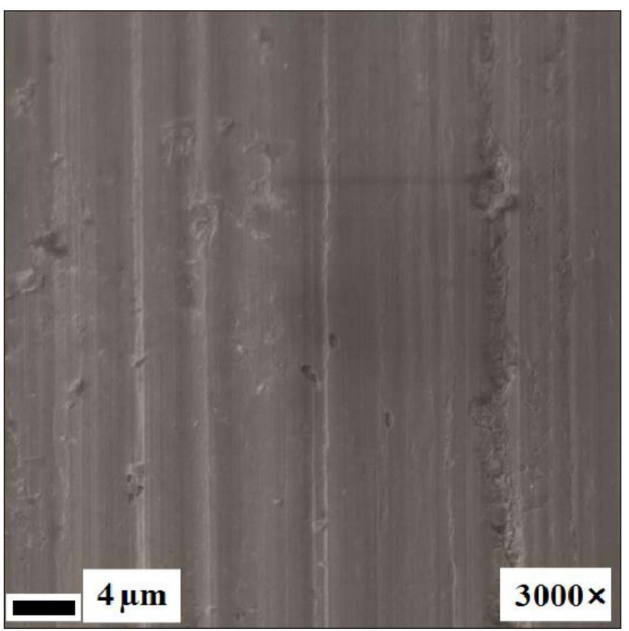

Figure 7. SEM image of the NiTi wire surface (mechanically treated in the direction of the long axis of the samples using diamond paste $(3 \mu \mathrm{m}$ followed by $1 \mu \mathrm{m}))$ after immersion for two years in Solution 2 (Table 1 ) at $\mathrm{pH} 3.56$.

Table 4. Surface composition of mechanically treated NiTi samples after immersion in various solutions for two years.

\begin{tabular}{|c|c|c|c|c|c|}
\hline Solution $\mathrm{pH}$ & 1.68 & 3.56 & 4.01 & $6.31 / 7.36$ & 9.18 \\
\hline Oxide layer thickness (nm) & $8-13$ & $13-17$ & $15-20$ & $23-28$ & $\sim 10$ \\
\hline $\begin{array}{l}\text { Nickel surface concentration } \\
\text { (atomic \%) }\end{array}$ & 8 & 5 & 3 & 0 & 3 \\
\hline Depth of nickel etching (nm) & 10 & 10 & 10 & 20 & 10 \\
\hline $\begin{array}{l}\text { Maximum oxygen surface } \\
\text { concentration (atomic \%) }\end{array}$ & \multicolumn{5}{|c|}{$\sim 60-70$ atomic. $\%$ at a depth of $2.5-7 \mathrm{~nm}$} \\
\hline
\end{tabular}

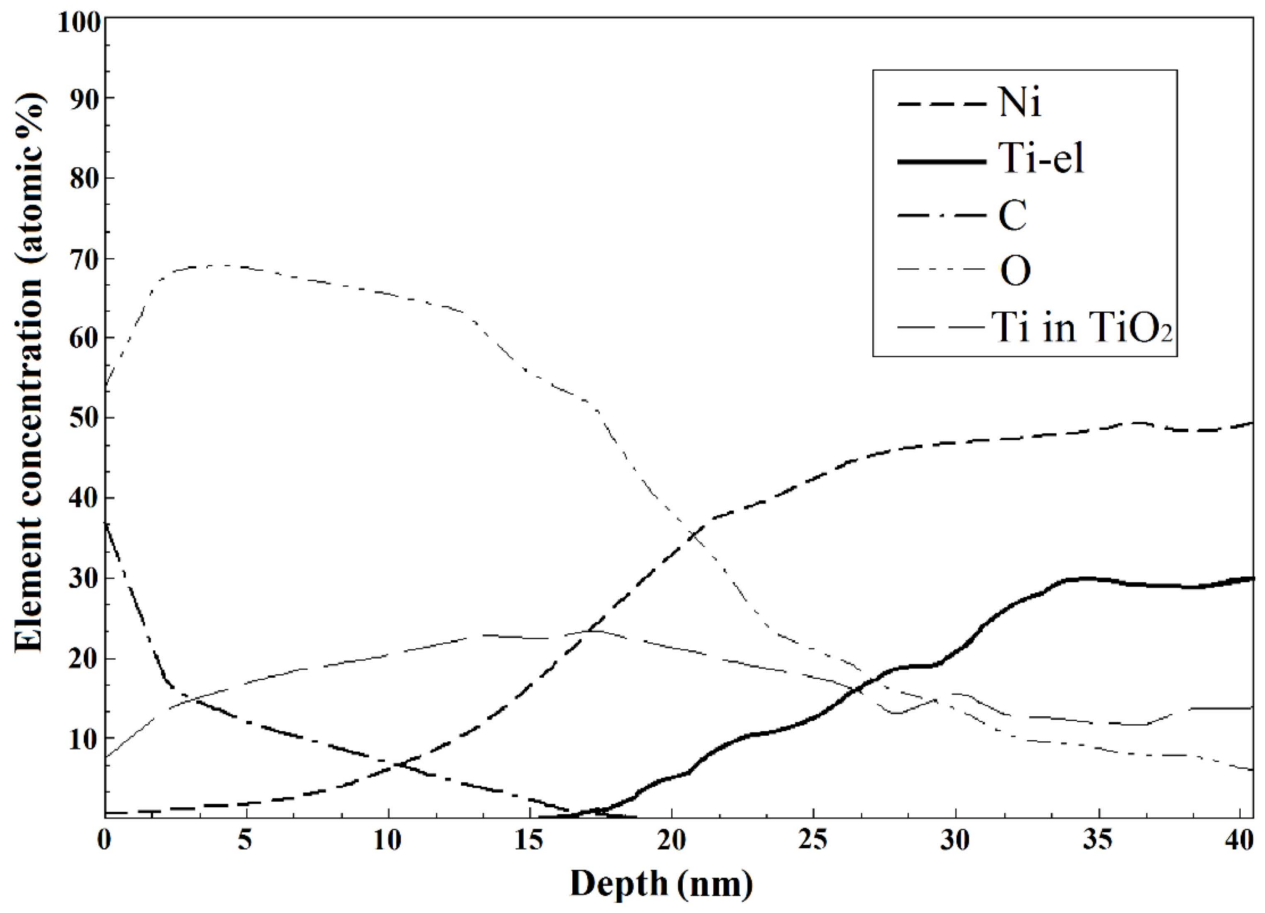

Figure 8. Composition of the NiTi wire surface mechanically treated in the direction of the long axis of the samples using diamond paste $(3 \mu \mathrm{m}$ followed by $1 \mu \mathrm{m})$ after immersion for two years in $0.9 \mathrm{wt} \%$ $\mathrm{NaCl}$ (Solution 4, Table 1), as determined by Auger spectroscopy. "Ti in $\mathrm{TiO}_{2}$ " and "Ti-el" mean bonded and elemental forms of $\mathrm{Ti}$, respectively. 
The surface of the wire samples immersed in artificial plasma was observed to contain $\mathrm{Ca}, \mathrm{P}, \mathrm{Na}$, and K (Figure 9), which can be attributed to inorganic sedimentation.

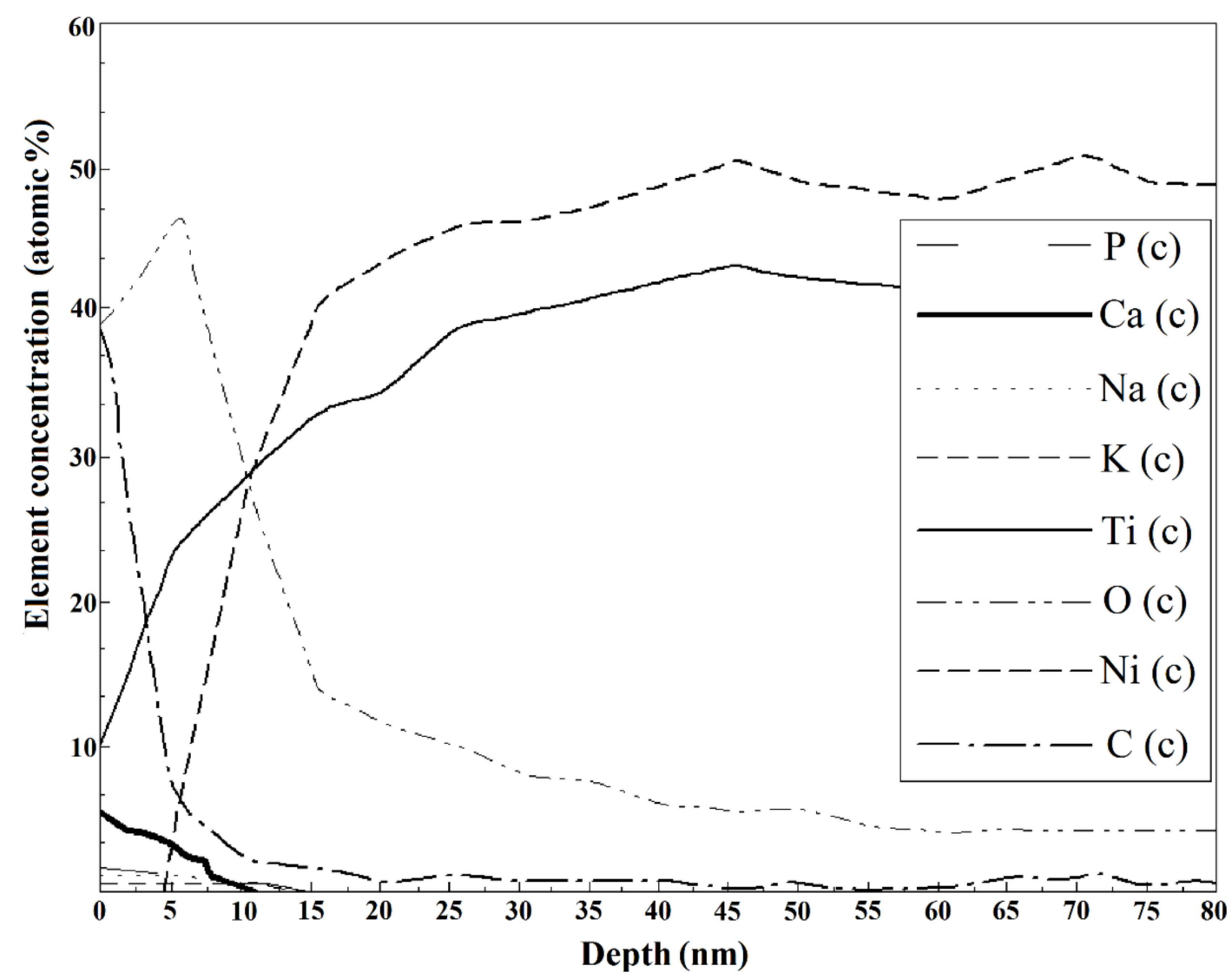

Figure 9. Composition of the NiTi wire surface mechanically treated in the direction of the long axis of the samples using diamond paste $(3 \mu \mathrm{m}$ followed by $1 \mu \mathrm{m})$ after immersion for two years in artificial plasma (Solution 6, Table 1) as determined by Auger spectroscopy.

\subsection{Metallic Ion Release in Solutions}

The results of long-term examinations (two years) of metallic ion release from the nanostructured NiTi samples placed in acid solutions and normal saline are presented in Table 2 and Figures 10 and 11. The results indicate the occurrence of slight corrosion in the solutions. In the case of the samples placed in alkaline solution, as noted earlier, and in artificial plasma, no release of metal into the solution was observed during the test period. Therefore, no corresponding marks are provided in Table 2 and in the figures. 

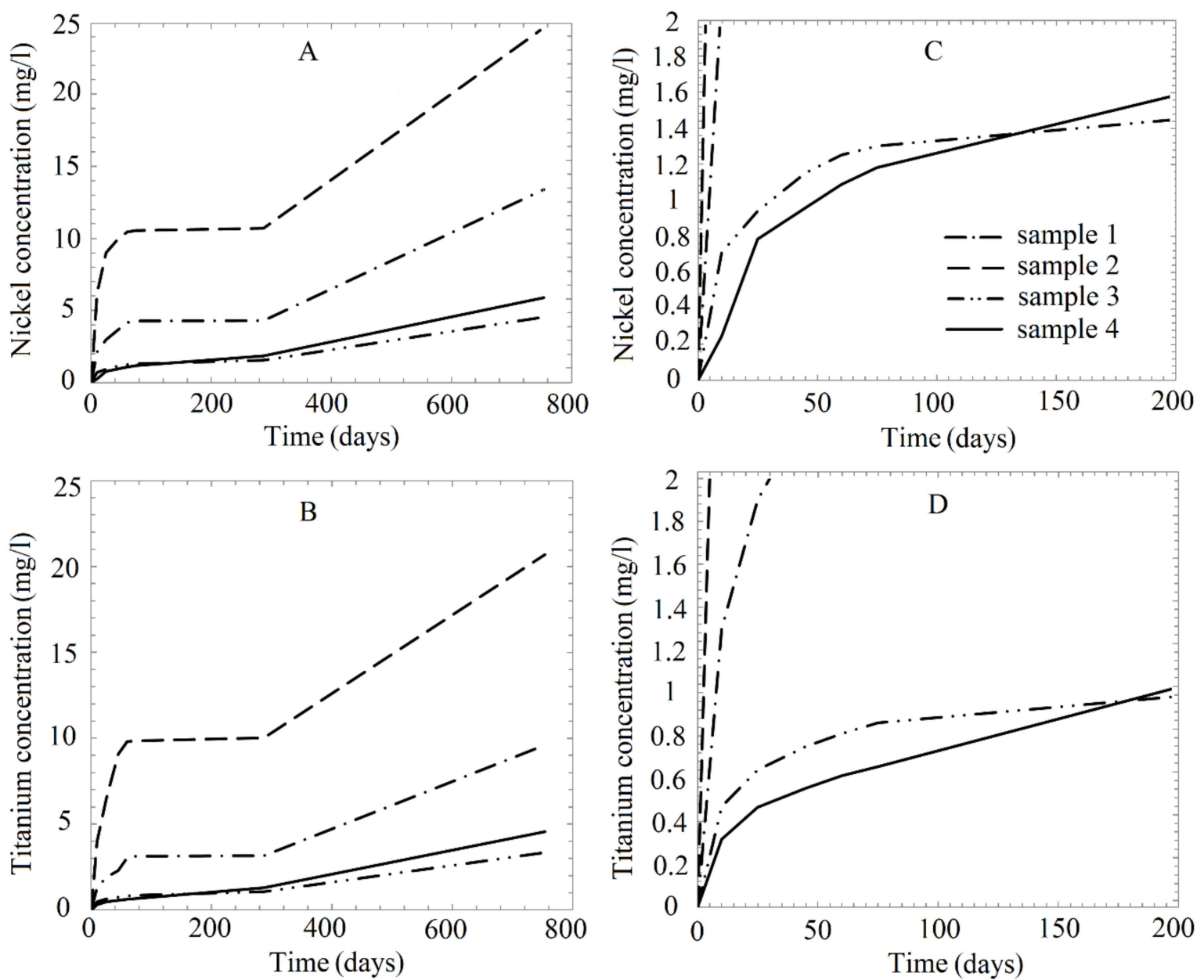

Figure 10. Change in the concentration of ions over time as each type of NiTi wire sample (Sample 1 as-received, Sample 2 - annealed at $450{ }^{\circ} \mathrm{C}$ for $15 \mathrm{~min}$, Sample 3 - mechanically treated in the direction of the long axis of the samples using diamond paste ( $3 \mu \mathrm{m}$ followed by $1 \mu \mathrm{m})$, and Sample 4 - mechanically treated and annealed) was immersed in a buffer solution at pH 1.68 (Solution 1, Table 1): (A,C) nickel and $(\mathbf{B}, \mathbf{D})$ titanium.

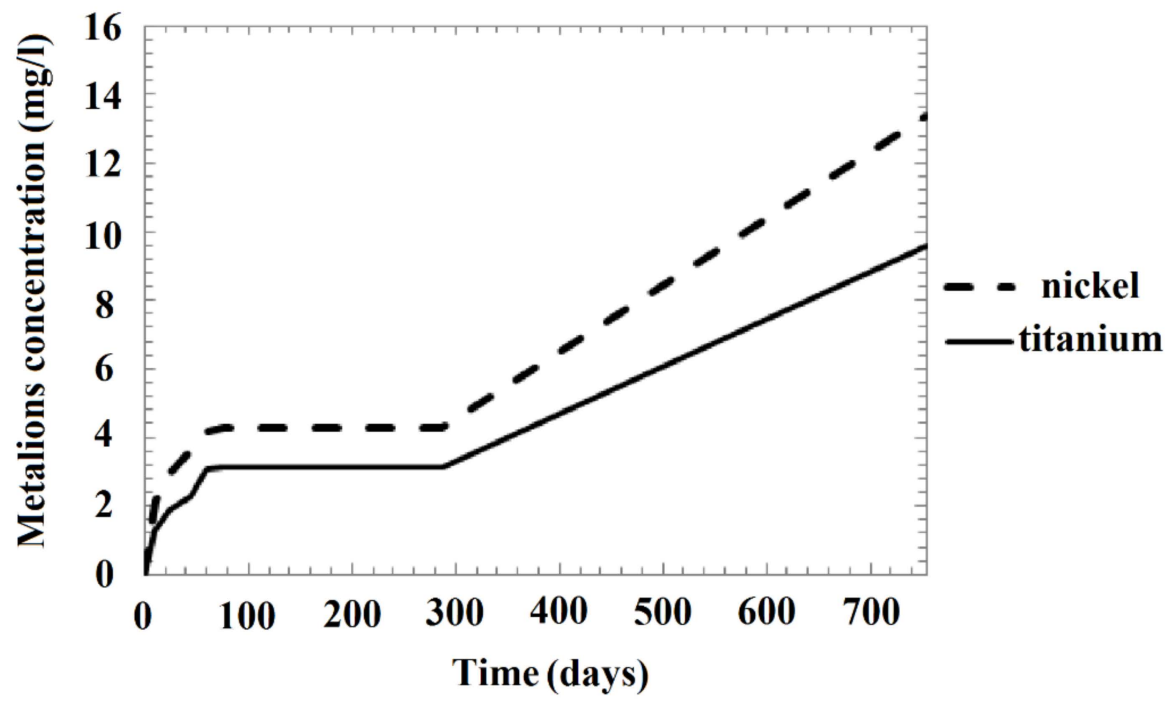

(a)

Figure 11. Cont. 


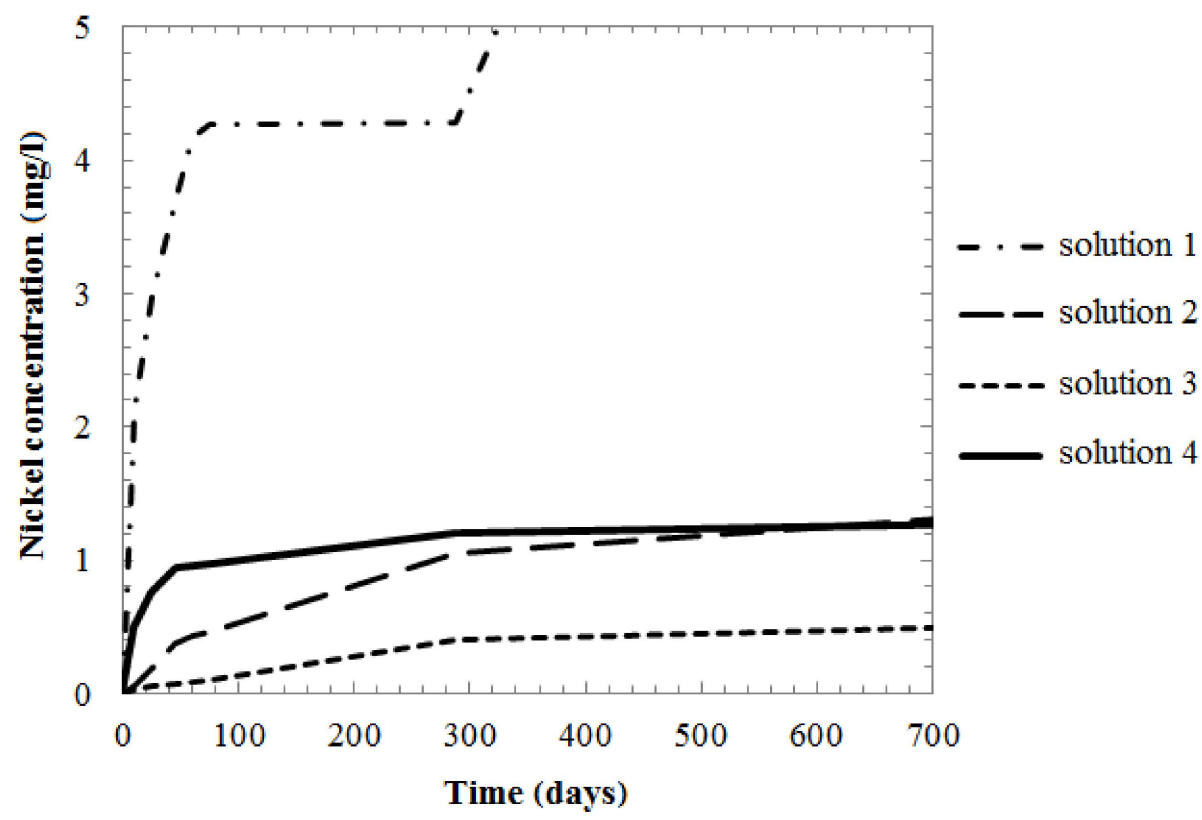

(b)

Figure 11. Changes in the concentration of ions dissolved from the as-received nitinol sample with time during immersion for 2 years: (a) nickel and titanium ion concentrations in a buffer solution at $\mathrm{pH}$ 1.68 (Solution 1, Table 1); and (b) nickel ion concentration in solutions with various acidities (Solution 1 - pH 1.68 buffer, Solutions 2 - pH 3.56 buffer, Solution 3 - pH 4.01 buffer, Solution 4 - NaCl, Table 1).

The annealed samples were the most prone to corrosion (Figure 10): their nickel and titanium release was found to be three-times higher than that of the untreated samples. The rates of change of the $\mathrm{Ni}$ and $\mathrm{Ti}$ concentrations in solution over time were almost the same. Expectedly, the corrosion resistance of the mechanically treated NiTi samples was significantly higher than that of the as-received samples. However, the wire diameters changed disproportionately with the ion concentrations in the solutions (Table 3). For example, the diameters of the as-received and annealed wires were similar after storage in the $\mathrm{pH} 1.68$ solution.

The release of ions was continuous during the two-year duration of the experiment; the concentrations of both nickel and titanium ions in solution increased with time (Figure 11a). However, the variation in the concentration of the $\mathrm{Ni}$ ions depended on the solution type, as shown in Figure 11b. The figure shows that the gradient of the $\mathrm{Ni}$ ion concentration in $\mathrm{NaCl}$ decreases smoothly with time until a constant concentration is attained. The Ni ion concentration in the weakly acidic solution was initially lower than that in the neutral chloride-containing solution, but increased after approximately 600 days. In the strongly acidic solution ( $\mathrm{pH} 1.68$ ), the sharp increase in the ion concentration resumed after a temporary plateau.

The buffer solutions used in the present study are not representative of typical physiological liquids and were only used to create environments with different $\mathrm{pH}$ values. Their effects on NiTi were thus compared with that of $0.0275 \mathrm{M}$ hydrochloric acid. The Ni and Ti concentrations in the $\mathrm{HCl}$ solution with as-received NiTi sample after 10 days were 1.94 and $0.515 \mathrm{mg} / \mathrm{L}$, respectively (Figure 10a, Table 2).

\section{Discussion}

\subsection{Structure Analysis Before and After Corrosion}

The presence of a thick mixed-composition layer on the surface of the as-received wire (Figure 3) was presumed to be due to the prolonged intermediate heat treatments during wire 
production $[16,19,26,42-46]$. It is thus unlikely that annealing the wire for 15 min would have significantly affected the surface composition. The abundance of carbon in the wire samples (Figure 3B) is likely due to the use of graphite-containing lubricants during the wire drawing process, with the lubricant remaining on the wire surface being fixated by the annealing. The presence of impurities on the surface of a NiTi sample after several cycles of treatment involving the use of a lubricant containing these elements was previously reported [25]. Our data fully agree with the data reported in previous studies [79].

The removal of the surface impurities and defects, reduction of the contact area, and formation of a more uniform passivating film (i.e., the observed homogeneous $\sim 10 \mathrm{~nm}$-thick oxide layer (Figures $2 \mathrm{C}$ and $3 \mathrm{C}$ ), or the previously reported $\sim 4 \mathrm{~nm}$-thick oxide layer on polished samples [24]) that result from the mechanical treatment evidently increase the corrosion resistance of the material. However, the presence any $\mathrm{Ni}$ on the surface, even if only a small amount, is undesirable. A thin passivating oxide layer is preferable because it is more flexible and can adapt to applied loads [42], although the layer must be thicker than $100 \mathrm{~nm}$ to act as an anticorrosive barrier [25]. Thus, the thin surface oxide layer formed in this study does not offer optimal protection against corrosion.

The surface composition of the mechanically treated samples after immersion for two years (Figure 8) agrees with the observations in Hu T. et al. [24], who also reported that the surface layer of polished samples immersed in $\mathrm{NaCl}$ solutions, as noted here, contains only titanium oxides, with $\mathrm{Ti}$ (corresponding to the NiTi phase) appearing and then increasing with increasing depth, gradually becoming more dominant. No $\mathrm{Ni}$ was observed on the corroded surface immersed in $\mathrm{NaCl}$ because of the release of $\mathrm{Ni}$ ions into the corroding solution, whereas Ti remained on the wire surface and reacted with the dissolved $\mathrm{O}$ in the solution to form an oxide layer in the damaged areas.

Inorganic sedimentation (Figure 9) can result in the prevention of the dissolution of $\mathrm{Ni}$ and $\mathrm{Ti}$ in an artificial plasma solution $[14,23,26,67,80]$. This inorganic-sedimentation layer may provide additional protection against corrosion.

Previous studies have shown that the exposure of NiTi to a hostile environment for an extended period leads to the formation of a thickened oxide layer [24]. This was substantiated by our reported observations (Figure 8 and Table 4).

\subsection{Metallic Ion Release in Solutions}

Notably, during the initial period of the studies, the release of ions from sample 3 was higher than from sample 4, and after 140-180 days, the opposite was observed (Figure 10). We assumed that, at first, the thicker surface layer of the sample after mechanical surface treatment and annealing acted as a better barrier against the diffusion of ions into the solution; however, an increase in the heterogeneity of the outer oxide layer as a result of heat treatment did not slow the leaching of elements as effectively as the more uniform passive film originally obtained by mechanical surface treatment [79].

Based on previous reports, we attribute the plateau in the concentration curve (Figure 11) to the sequential destruction and renewal of the protective oxide layer (i.e., depassivation and repassivation) in the defect areas $[17,24,26,81]$. We propose that these processes occurred in all solutions, with the concentration variation being less noticeable compared to the highly acidic solution.

Our observations of the rate of concentration change (Figure 11) and the surface conditions (Figure 5) for the most acidic solution are similar to previous reports for $\mathrm{NaCl}$ [24]. Specifically, after the formation of pitting pores, which grow into larger holes surrounded by new pitting pores, the release of Ni increases; however, the oxide layer then decreases the corrosion speed by sealing the pores.

Previous studies found that the maximum rate of $\mathrm{Ni}$ ions release occurred at the beginning of the test before the rate reduced dramatically (for the period from 8 to 14 days to several months) due to the thickening of the oxide layer, which serves as a protective barrier [13-24,27,33]. From evaluations of the repassivation processes that occur under static and dynamic conditions and after surface damage, nitinol is resistant to the destruction of the passive layer under dynamic loading, and has a greater tendency for repassivation compared to 316L stainless steel [13,81-83]. Samples 
of NiTi wires of different compositions have also been observed to develop passivation layers with the same composition after immersion in solutions, with the layers consisting of $\mathrm{Ni}$-containing $\mathrm{Ti}$ oxides $[14,20,23]$. The possibility of repassivation was also noted in these previous works.

Each sample type in the present study exhibited the highest ion release in the most acidic environment (Figure 11b), with the ion release decreasing with increasing $\mathrm{pH}$ value, and then beginning to increase again in the neutral $\mathrm{NaCl}$. Under all the considered test conditions, more Ni ions were released than Ti ions (Figures 10 and 11a).

We found that exposure to a saline solution leads to a high level of metal ion release. During the early stage of the test, the ion release was higher than those in $\mathrm{pH} 4.01$ and 3.56 solutions, with the metal ion concentration in the saline solution remaining higher than in the $\mathrm{pH} 4.01$ solution after the first 600 days (Figure 4b; Table 2). The saline solution is a sufficiently concentrated source of chloride ions, which have higher affinity for metals than $\mathrm{O}$ and thus replace $\mathrm{O}$ in the protective oxide surface layer, resulting in depassivation and pitting [84,85]. The speed of the NiTi corrosion process was observed to increase with increasing chloride concentration in the saline solution, being strongly dependent on the surface conditions [86]. It was noted that NiTi corroded via pitting at an appropriate chloride concentration across the entire $\mathrm{pH}$ range and the pitting potential did not vary with the $\mathrm{Ni}$ ion concentration [87].

Withalmetallic ion release and surface damage increased with increasing acidity (Figure $4 a$, Figure 5a,b and Figure 10; Figure 11b; Table 2), which indicates an increasingly hostile environment. Whereas the findings of some studies suggest that acidity has a negligible impact on the corrosion resistance of NiTi $[88,89]$, others have linked an increase in the corrosion rate, observed as an increase in the rate of $\mathrm{Ni}$ ion release, to decreasing $\mathrm{pH}[14,23,31]$. Another study [87] showed that the breakdown potential in an alkaline environment was $100 \mathrm{mV}$ higher than in an acidic environment, where it was 100-200 $\mathrm{mV}$ higher than in a neutral environment (attributed to the general etching of the alloy surface in an acidic solution). This agrees with our observations that no corrosion occurs in an alkaline medium (Figure 5d; Table 3).

When comparing the effect of buffer solutions and hydrochloric acid on nitinol, we noted that the dissolved Ni content after a short exposure to the $\mathrm{pH} 1.56 \mathrm{HCl}$ was comparable with that in the $\mathrm{pH} 1.68$ buffer solution (Figure 10a; Table 2). However, the titanium concentration in the buffer solution was two-times higher than that in the $\mathrm{HCl}$ (Figure 10b; Table 2). Expectedly, the $\mathrm{pH}$ of the $\mathrm{HCl}$ solution was unstable and increased to $\mathrm{pH} 2.00$ after two years of carrying the NiTi wires. The surface of the wires after long-term exposure to $\mathrm{HCl}$ (Figure 5e) resembled that of the wires immersed in $\mathrm{NaCl}$ solution (Figure $5 \mathrm{c}$ ), although the former suffered more corrosion damage. In contradistinction to the samples exposed to the highly acidic buffer solution with the most serious pitting surface damage samples after exposure to $\mathrm{HCl}$ were covered with a rough and presumably oxide layer. The changes in the wire diameter in $\mathrm{HCl}$ (Table 3) were also significantly less than those in the acidic $\mathrm{pH} 1.68$ buffer solution.

From the observed ratios between the amounts of released $\mathrm{Ni}$ and $\mathrm{Ti}$ ions, the wire diameter changes (Table 3), and the surface morphology changes (Figure 4a; Figure 5c,e) in this study, we inferred that the behaviors of NiTi in acidic $(\mathrm{HCl})$ and neutral $(\mathrm{NaCl}$ and plasma) chloride-containing environments are more similar than those in the two acidic solutions ( $\mathrm{HCl}$ and $\mathrm{pH} 1.68$ buffer solution). The surface of the NiTi wire samples in $\mathrm{HCl}$ was observed to be covered with a protective layer. We assumed that the amounts of $\mathrm{Ni}$ ions released in the two acidic environments are comparable, whereas more titanium will be consumed in the formation of a protective oxide layer, as in neutral media.

However, as noted earlier, the solutions and conditions considered in the present study are not representative of physiological conditions and were only used to model some corrosion parameters. Although this enabled the acquisition of some information about the typical behavior of NiTi, further biological investigations are required to properly predict the behavior of the alloy in physiological systems. 


\subsection{Effect of Nanostructure and Treatment on Corrosion Behavior}

Polycrystalline NiTi is a self-passivated material, like Ti or stainless steel. The grain boundaries contain many $\mathrm{O}$ atoms, which create a nonstoichiometric oxide film around each grain through their reaction with Ti (TiII, TiIII, and TiIV species). This stable surface layer protects each grain and the base material against corrosion $[1,24,90]$. Therefore, increasing the number of grain boundaries in the volume of the alloy could increase its corrosion resistance and biocompatibility. However, the high density of intergranular surface defects could lead to a poor corrosion performance since corrosion attack typically initiates at surface heterogeneities [91]. This has been little studied.

Here, the concentrations of the Ni released from the nanostructured NiTi into the different solutions (Table 2) were lower than the previously reported average values for microstructured NiTi [22-33]. Examples of the reported nickel release in solutions similar in composition and/or acidity to the solutions used in this study are summarized in Table 5. These values are widely different, even within one study.

We unexpectedly found that Ti ions were released in all the solutions considered in this study (Figures 10 and 11). The only exceptions were the cases of the mechanically treated samples in the neutral and pH 4.01 solutions. - In case of other samples and solutions, it can be noted that the concentrations of the $\mathrm{Ti}$ and $\mathrm{Ni}$ ions were similar in the $\mathrm{pH} 1.68$ solutions, but differed by one to two orders of magnitude in the other solutions (Table 2).

Table 5. Nickel concentrations in various solutions for various immersion times and nitinol samples types reported in the literature.

\begin{tabular}{|c|c|c|c|c|}
\hline \multirow[b]{2}{*}{ Solution } & \multicolumn{4}{|c|}{ Ni Concentration in Solution $(\mathrm{mg} / \mathrm{L})$} \\
\hline & $\begin{array}{l}\text { Time } \\
\text { (Days) }\end{array}$ & $\begin{array}{l}\text { As-Received Sample } \\
\text { (Commercial) }\end{array}$ & $\begin{array}{l}\text { Mechanically Treated } \\
\text { and/or Electropolished } \\
\text { Sample }\end{array}$ & Reference \\
\hline \multirow{5}{*}{$0.9 \% \mathrm{NaCl}$} & 15 & $0.005-1.000$ & & \multirow{5}{*}{ [25] } \\
\hline & 30 & $0.010-1.480$ & & \\
\hline & 60 & $0.020-1.620$ & & \\
\hline & 120 & $0.025-1.760$ & & \\
\hline & 180 & $0.030-1.800$ & & \\
\hline \multirow{7}{*}{$\begin{array}{c}\text { Hank's physiological } \\
\text { solution } \\
\text { (pH 7.4) }\end{array}$} & 1 & 0.200 & 0.200 & \multirow{6}{*}[26]{} \\
\hline & 2 & 0.300 & 0.220 & \\
\hline & 6 & $0.350-0.400$ & 0.250 & \\
\hline & 9 & $0.500-0.850$ & 0.250 & \\
\hline & 14 & $0.550-0.900$ & 0.250 & \\
\hline & 18 & $0.600-1.050$ & 0.250 & \\
\hline & 1 & & 1.300 & [27] \\
\hline \multirow{5}{*}{$\begin{array}{l}\text { Simulated body fluid } \\
\text { (SBF) } \\
(\mathrm{pH} 7.4)\end{array}$} & 14 & & 0.195 & \multirow{3}{*}{ [28] } \\
\hline & 35 & & 0.205 & \\
\hline & 70 & & 0.500 & \\
\hline & 30 & & 0.290 & [29] \\
\hline & 35 & 0.950 & & [30] \\
\hline \multirow{4}{*}{$\begin{array}{l}\text { (cell-free) Culture } \\
\text { medium } \\
(\mathrm{pH} \mathrm{7.4)}\end{array}$} & 2 & 0.152 & & [32] \\
\hline & 2 & 118.930 & & [33] \\
\hline & 3 & & 0.081 & \multirow{2}{*}{ [22] } \\
\hline & 6 & & 0.176 & \\
\hline
\end{tabular}


Table 5. Cont.

\begin{tabular}{|c|c|c|c|c|c|}
\hline \multirow{2}{*}{\multicolumn{2}{|c|}{ Solution }} & \multicolumn{4}{|c|}{ Ni Concentration in Solution (mg/L) } \\
\hline & & $\begin{array}{c}\text { Time } \\
\text { (Days) } \\
1\end{array}$ & $\begin{array}{c}\begin{array}{c}\text { As-Received Sample } \\
\text { (Commercial) }\end{array} \\
0.255-1.275\end{array}$ & \multirow{2}{*}{$\begin{array}{l}\text { Mechanically Treated } \\
\text { and/or Electropolished } \\
\text { Sample }\end{array}$} & Reference \\
\hline \multirow{3}{*}{$\begin{array}{l}\text { Artificial } \\
\text { saliva }\end{array}$} & $\mathrm{pH} 2.5$ & $\begin{array}{c}1 \\
3 \\
7 \\
14 \\
28\end{array}$ & $\begin{array}{c}0.255-1.275 \\
1.530-4.080 \\
2.040-5.610 \\
4.080-10.200 \\
4.080-15.300\end{array}$ & & \multirow{3}{*}{ [23] } \\
\hline & pH 3.75 & $\begin{array}{c}1 \\
3 \\
7 \\
14 \\
28\end{array}$ & $\begin{array}{l}0.128-0.893 \\
0.255-1.020 \\
0.255-1.275 \\
0.255-1.785 \\
0.383-2.550\end{array}$ & & \\
\hline & $\mathrm{pH} 6.25$ & $\begin{array}{c}1 \\
3 \\
7 \\
14 \\
28\end{array}$ & $\begin{array}{l}0.038-0.191 \\
0.153-0.561 \\
0.153-0.714 \\
0.153-0.714 \\
0.153-0.765\end{array}$ & & \\
\hline \multicolumn{2}{|c|}{$0.9 \% \mathrm{NaCl}$} & $\begin{array}{c}2 \\
5 \\
8 \\
12 \\
30\end{array}$ & & $\begin{array}{l}0.013 \\
0.020 \\
0.050 \\
0.065 \\
0.120\end{array}$ & [24] \\
\hline
\end{tabular}

The dissolutions of both $\mathrm{Ni}$ and $\mathrm{Ti}$ in the acidic organic buffer solutions (pH 1.68-4.01) can be explained by the fact that complex salts are produced when these ions interact with potassium tetraoxalate, tartrate, and phthalate [84]. Titanium is considered to have satisfactory resistance to chloride-containing environments, with the pitting potentials of $\mathrm{Ni}$ and $\mathrm{Ti}$ in $0.1 \% \mathrm{NaCl}$ at $25^{\circ} \mathrm{C}$ being +0.28 and $+12.0 \mathrm{~V}$, respectively, which is a difference of exactly two orders of magnitude $[84,85]$.

However, according to literature data, Ni ions are released into the solution after corrosion, while Ti remains on the surface and reacts with the dissolved $O$ to form an oxide layer [24]. Previous reports also suggested the presence of a subsurface $\mathrm{Ni}_{3} \mathrm{Ti}$ layer and pure $\mathrm{Ni}$ particles measuring 10-100 $\mathrm{nm}$ between the surface oxide layer and the bulk alloy, attributable to the formation of a thick $\mathrm{TiO}_{2}$ layer $[25,42,62]$. The reaction of $\mathrm{O}$ with $\mathrm{Ti}$ is more thermodynamically favorable than that of $\mathrm{O}$ with $\mathrm{Ni}$. A thin layer of titanium oxide thus begins to form spontaneously on the NiTi surface when it is exposed to an O-containing environment. This oxidation changes the crystalline structure of the NiTi surface and forms a Ni-enriched sublayer, which contains vacancies where the Ti atoms were knocked out from their position in the crystal lattice [92]. The $\mathrm{Ni}$ atoms can be released from their bonds with $\mathrm{Ti}(\mathrm{Ni}-\mathrm{Ti})$ at close to room temperature, with the atoms subsequently occurring as crystalline defects-interstitial atoms in the structure of the surface oxide. This oxide is typically non-stoichiometric due to its $\mathrm{O}$ deficiency. The sites of the missing $\mathrm{O}$ atoms also constitute structural vacancies, which allows the diffusion of $\mathrm{Ni}$ through the oxide layer even at a low temperature due to the smaller size of the $\mathrm{Ni}$ atoms compared with the Ti and $\mathrm{O}$ atoms. Thus, $\mathrm{Ni}$ could dissolve from the surface of the NiTi sample as well as from the subsurface layers, while Ti remains in the sample and forms a protective oxide surface layer that thickens with time, as can also be observed from Figures 8 and 10 [24,25,33,42].

We also found evidence of the selective dissolution of metals [23,93]. In a previous study, Ti was observed to leach only into acidic solutions and $\mathrm{Ni}$ into both acidic and neutral solutions, and the surface damage caused by the leaching was subsequently repaired by titanium oxide formation after $\mathrm{Ni}$ etching [93]. In another study, Ti ions were observed to only be released in artificial saliva at $\mathrm{pH} 2.5$, and not in less acidic or neutral solutions [23]. 
Our observation of the release of Ti ions into neutral solutions was thus unexpected, although the $\mathrm{Ti}$ ion concentration was lower than that of the $\mathrm{Ni}$ ions for all the investigated solutions (Figure 10, Figure 11a; Table 2). However, as Ti ion release was only observed for the non-mechanically treated samples (Table 2), the release was apparently controlled by the NiTi nanostructures. We speculate that the fine grains in the areas with a high density of defects completely broke down with the washing-out of $\mathrm{Ni}$, resulting in Ti release. Although Ti is not considered to be harmful to the human body, even at much higher concentrations, the nanostructure has a double effect on the corrosion resistance of nitinol.

This effect was also confirmed by previous reports. For example, Amirhanova N.A. et al. [94] observed an ambiguous effect of the nanostructures of NiTi with grain diameters less than $10 \mathrm{~nm}$. The corrosion resistance was found to be substantially lower in $\mathrm{HCl}$ solution compared with the microstructured NiTi due to the larger number of grain boundaries and structural defects. However, the alloy was more corrosion resistant in $\mathrm{NaCl}$ solutions. In other studies [91,95-97], no difference was found between the corrosion processes of micro- and nanostructured NiTi. However, nanostructured Ti was found to exhibit reduced corrosion resistance [98]. However, a positive influence on the mechanical properties of the materials was noted in these studies.

The observed effects of the treatment methods used in this study on the ion release agree closely with previous reports on microstructural nitinol, suggesting that heat treatment significantly reduces the corrosion resistance due to the mixed formation of surface layers containing titanium oxide and $\mathrm{Ni}$ oxide $[16,19,42,44,45]$. The negative effects of the heat treatment (Figure $4 a, b ;$ Figure 10) may also be attributed to the drawing back and recrystallisation of the outer cold-worked layer formed during the wire fabrication process. Thus, the behavior of the nanostructured nitinol after heat treatment does not differ from the microstructural behavior.

However, the effects of the mechanical treatment were found to be greater (Figure 7; Table 2) than those previously reported $[16,26,27,45]$. No Ti release from the mechanically treated samples was observed in the solutions with $\mathrm{pH} 4.01-6.31$, in contrast to the observation in the $\mathrm{pH} 1.68$ solution and for the other samples. Based on the present observation of a significant reduction in the Ni ion release (and generally low concentration in solutions) and no Ti ion release from the mechanically treated NiTi samples (and no metal release in artificial plasma), as well as the structural analysis of mechanically treated nitinol samples after exposure to these solutions (Figure 7, Figure 8; Table 2), we conclude that a strong homogenous protective layer of titanium oxide formed on the surface of the samples, creating a barrier to Ni dissolution. That is, a combination of nanostructuring and subsequent mechanical treatment significantly positively affects the corrosion resistance of NiTi.

Notably, the above observations occurred under static conditions, which may not be representative of physiological conditions. The formation of a heterogenous mixed layer of $\mathrm{Ti}$ and $\mathrm{Ni}$ oxides after annealing, which is a necessary process for obtaining a finished NiTi device, would expose live tissues to direct contact with toxic $\mathrm{Ni}$ and also allow for Ni diffusion into the surrounding environment.

The use of nanostructured NiTi for medical implants and devices thus remains prospective compared with microstructured $\mathrm{NiTi}$, although the formation of a corrosion-resistant and biocompatible surface layer is a desirable feature.

\section{Conclusions}

Less $\mathrm{Ni}$ was released from the nanostructured NiTi samples investigated in this study in solutions with different acidity levels than from microstructured NiTi. Mechanical treatment was found to increase the corrosion resistance of NiTi by two- to three-fold. Heat treatment reduced the corrosion resistance of the samples, and the nanostructures apparently induced the release of Ti ions in solutions with any acidity. The highest concentration of metals was observed in solutions with the highest acid concentration. Smaller amounts of metal were found to be released into neutral saline, and the lowest amounts into weakly acidic solutions. Metal dissolution did not occur in an alkaline environment and artificial plasma. The metal concentration in solutions increased over time, but the rates of increase varied for different samples and solutions. 
Significantly less $\mathrm{Ni}$ and no $\mathrm{Ti}$ was released from the mechanically treated samples in neutral and weakly acidic solutions, whereas no metal was released whatsoever in artificial plasma. This implies the formation of a strong and homogenous protective titanium oxide layer that prevents Ni dissolution. This layer afforded the high corrosion resistance of the mechanically treated nanostructured NiTi samples.

The surface compositions of the as-received and the unpolished annealed wires were observed to be similar, consisting of interspersed areas of carbon- and titanium-oxide-rich spots that reached depths of $3 \mu \mathrm{m}$. The long exposure of the wire samples to different solutions did not significantly change the surface composition. Mechanical treatment of the wire surface resulted in the formation of a thin uniform titanium oxide layer, and reduced the surface roughness and defects, although it did not entirely remove $\mathrm{Ni}$ from the surface. A Ni-free surface with a protective $25 \mathrm{~nm}$-thick titanium oxide film resulted from soaking mechanically treated samples of the NiTi wire in a saline solution for two years under static conditions. Such conditions are, however, impractical in medical applications.

Hence, the medical application of nanostructured NiTi, such as for the production of medical devices and implants such as stents, remains prospective compared to microstructured NiTi. However, the formation of a corrosion-resistant and biocompatible surface layer is a desirable feature of nanostructured NiTi.

Author Contributions: Conceptualization, M.A.S. (Maria A. Sudarchikova); Funding acquisition, E.O.N. and M.A.S. (Mikhail A. Sevost'yanov); Investigation, E.O.N.; Methodology, E.O.N.; Project administration, M.A.S. (Mikhail A. Sevost'yanov); Supervision, M.A.S. (Mikhail A. Sevost'yanov); Validation, S.V.K.; Visualization, K.V.S.; Writing—original draft, E.O.N.; Writing—review \& editing, E.O.N. and M.A.S. (Maria A. Sudarchikova).

Funding: This work was supported by the Russian President Program for Young Scientists (MK-4521.2018.8). Nanostructured nitinol production research was funded by the state assignment No. 075-00746-19-00.

Acknowledgments: The authors thank Golberg, M.A.; Dyomin, K.Y.; Mikhailova, A.B.; and Volchenkova, V.A. for their assistance with the sample analyses.

Conflicts of Interest: The authors declare no conflict of interest. The funders had no role in the design of the study; in the collection, analyses, or interpretation of data; in the writing of the manuscript, or in the decision to publish the results. All the authors have reviewed the manuscript and agree on submission to your journal.

\section{References}

1. Gunther, V.E.; Hodorenko, V.N.; Yasenchuk, Y.F.; Chekalkin, T.L. Nikelid Titana, Meditsynsky Material Novogo Pokoleniya [Titanium Nickelide, Medical Material of New Generation]; MITs Publishing House: Tomsk, Russia, 2006.

2. Petrini, L.; Migliavacca, F. Biomedical applications of shape memory alloys. J. Metall. 2011, 2011, 1-15. [CrossRef]

3. Pelton, A.R.; Huang, G.H.; Moine, P.; Sinclair, R. Effects of thermal cycling on microstructure and properties in nitinol. Mater. Sci. Eng. 2012, 532, 130-138. [CrossRef]

4. Duerig, T.W.; Melton, K.N.; Wayman, C.M.; Stockel, D. Engineering Aspects of Shape-Memory Alloys; Butterworth Heinemann Ltd.: Oxford, UK, 1990.

5. Stoeckel, D. Nitinol medical devices and implants. Minim. Invasive Ther. Allied Technol. 2000, 9, 81-88. [CrossRef]

6. Shabalovskaya, S. On the nature of the biocompatibility and medical applications of NiTi shape memory and superelastic alloys. Bio Med. Mater. Eng. 1996, 6, 267-289.

7. Zhang, Y.; Zhang, Z.; Xie, Y.; Wang, S.; Qiu, Q.; Zhou, Y.; Zeng, G. Toxicity of nickel ions and comprehensive analysis of nickel ion-associated gene expression profiles in THP-1 cells. Mol. Med. Rep. 2015, 12, 3273-3278. [CrossRef] [PubMed]

8. Shih, C.C.; Lin, S.J.; Chen, Y.L.; Su, Y.Y.; Lai, S.T.; Wu, G.J.; Kwok, C.F.; Chung, K.H. The cytotoxicity of corrosion products of nitinol stent wire on cultured smooth muscle cells. J. Biomed. Mater. Res. 2000, 52, 395-403. [CrossRef] 
9. Bour, H.; Nicolas, J.F.; Garrigue, J.L.; Demiden, A.; Schmitt, D. Establishment of nickel-specific T cell lines from patients with allergic contact dermatitis: Comparison of different protocols. Clin. Immunol. Immunopathol. 1994, 73, 142-145. [CrossRef]

10. Wataha, J.; O'Dell, N.; Singh, B.; Ghazi, M.; Whitford, G.; Lockwood, P. Relating nickel-induced tissue inflammation to Ni release in vivo. J. Biomed. Mater. Res. 2001, 58, 537-544. [CrossRef]

11. Uo, M.; Watari, F.; Yokoyama, A.; Matsuno, H.; Kawasaki, T. Dissolution of nickel and tissue response observed by X-ray scanning analytical microscopy. Biomaterials 1999, 20, 747-755. [CrossRef]

12. Lu, X.; Bao, X.; Huang, Y.; Qu, Y.; Lu, H.; Lu, Z. Mechanisms of cytotoxicity of nickel ions based on gene expression profiles. Biomaterials 2009, 30, 141-148. [CrossRef]

13. Trépanier, C.; Pelton, A.R. Effect of strain on the corrosion resistance of nitinol and stainless steel in simulated physiological environment. In Proceedings of the SMST: The International Conference on Shape Memory and Superelastic Technologies, Monterey, CA, USA, 5-8 May 2003; pp. 393-398.

14. Huang, H.H. Surface characterizations and corrosion resistance of nickel-titanium orthodontic archwires in artificial saliva of various degrees of acidity. J. Biomed. Mater. Res. 2005, 74, 629-639. [CrossRef] [PubMed]

15. Es-Souni, M.; Fischer-Brandies, H. On the properties of two binary NiTi shape memory alloys. Effects of surface finish on the corrosion behaviour and in vitro biocompatibility. Biomaterials 2002, 23, 2887-2894. [CrossRef]

16. Trepanier, C.; Tabizian, M.; Yahia, L.H.; Bilodeau, L.; Piron, D.L. Effect of modification of oxide layer on NiTi stent corrosion resistance. J. Biomed. Mater. Res. 1998, 43, 433-440. [CrossRef]

17. Sun, E.X.; Fine, S.; Nowak, W.B. Electrochemical behavior of nitinol alloy in Ringer's solution. J. Mater. Sci. Mater. Med. 2002, 13, 959-964. [CrossRef]

18. Trepanier, C.; Tabrizian, M.; Yahia, L.H.; Bilodeau, L.; Piron, D.L. Improvement of the corrosion resistance of NiTi stents by surface treatments. Mater. Res. Soc. Symp. Proc. 1997, 459, 363-368. [CrossRef]

19. Trepanier, C.; Fino, J.; Zhu, L.; Pelton, A.R. Corrosion resistance of oxidized Nitinol. In Proceedings of the SMST: The International Conference on Shape Memory and Superelastic Technologies, Monterey, CA, USA, 5-8 May 2003; pp. 267-276.

20. Huang, H.H. Variation in corrosion resistance of nickel-titanium wires from different manufacturers. Angle Orthod. 2005, 75, 661-665.

21. Figueira, N.; Silva, T.M.; Carmezim, M.J.; Fernandes, J.C.S. Corrosion behaviour of NiTi alloy. Electrochim. Acta 2009, 54, 921-926. [CrossRef]

22. Rocher, P.; El Medawar, L.; Hornez, J.C.; Traisnel, M.; Breme, J.; Hildebrand, H.F. Biocorrosion and cytocompatibility assessment of NiTi shape memory alloys. Scr. Mater. 2004, 50, 255-260. [CrossRef]

23. Huang, H.H.; Chiu, Y.H.; Lee, T.H.; Wu, S.C.; Yang, H.W.; Su, K.H.; Hsu, C.C. Ion release from NiTi orthodontic wires in artificial saliva with various acidities. Biomaterials 2003, 24, 3585-3592. [CrossRef]

24. Hu, T.; Chu, C.; Xin, Y.; Wu, S.; Yeung, K.W.K.; Chu, P.K. Corrosion products and mechanism on NiTi shape memory alloy in physiological environment. J. Mater. Res. 2010, 25, 350-358. [CrossRef]

25. Shabalovskaya, S.A.; He Tian Anderegg, J.W.; Schryvers, D.U.; Carroll, W.U.; Van Humbeeck, J. The influence of surface oxides on the distribution and release of nickel from nitinol wires. Biomaterials 2009, 30, 468-477. [CrossRef] [PubMed]

26. Cisse, O.; Savagodo, O.; Wu, M.; Yahia, L. Effect of surface treatment of NiTi alloy on its corrosion behavior in Hank's solution. J. Biomed. Mater. Res. 2002, 61, 339-345. [CrossRef] [PubMed]

27. Trepanier, C.; Venugopalan, R.; Messer, R.; Zimmerman, J.; Pelton, A.R. Effect of passivation treatments on nickel release from nitinol. In Proceedings of the 6th World Biomaterials Congress, Kamuela, HI, USA, 15-20 May 2000.

28. Chu, C.L.; Guo, C.; Sheng, X.B.; Dong, Y.S.; Lin, P.H.; Yeung, K.W.K.; Chu, P.K. Microstructure, nickel suppression and mechanical characteristics of electropolished and photoelectrocatalytically oxidized biomedical nickel titanium shape memory alloy. Acta Biomater. 2009, 5, 2238-2245. [CrossRef]

29. Michiardi, A.; Aparicio, C.; Planell, J.A.; Gil, F.J. New oxidation treatment of NiTi shape memory alloys to obtain Ni-free surfaces and to improve biocompatibility. J. Biomed. Mater. Res. 2006, 77, 249-256. [CrossRef] [PubMed] 
30. Liu, X.M.; Wu, S.L.; Chan, Y.L.; Chu Paul, K.; Chung, C.Y.; Chu, C.L.; Yeung, K.W.K.; Lu, W.W.; Cheung, K.M.C.; Luk, K.D.K. Surface characteristics, biocompatibility, and mechanical properties of nickel-titanium plasma-implanted with nitrogen at different implantation voltages. J Biomed. Mater. Res. 2007, 82, 469-478. [CrossRef] [PubMed]

31. Kanemura, T.; Yokoyama, K.; Sakai, J. Effects of acid type on corrosion and fracture behavior of Ni-Ti superelastic alloy under sustained tensile load in physiological saline solution containing hydrogen peroxide. Corros. Sci. 2008, 50, 2785-2795. [CrossRef]

32. Ryhanen, J.; Niemi, E.; Serlo, W.; Niemela, E.; Sandvik, P.; Pernu, H.; Salo, T. Biocompatibility of nickel-titanium shape memory metal and its corrosion behavior in human cell cultures. J. Biomed. Mater. Res. 1997, 35, 451-457. [CrossRef]

33. Tomić, S.; Rudolf, R.; Brunčko, M.; Anžel, I.; Savić, V.; Čolić, M. Response of monocyte-derived dendritic cells to rapidly solidified nickel-titanium ribbons with shape memory properties. Eur. Cells Mater. 2012, 23, 58-81. [CrossRef]

34. Clarke, B.; Kingshott, P.; Hou, X.; Rochev, Y.; Gorelov, A.; Carroll, W. Effect of nitinol wire surface properties on albumin adsorption. Acta Biomater. 2007, 3, 103-111. [CrossRef]

35. Bishara, S.E.; Barrett, R.D.; Selim, M.I. Biodegradation of orthodontic appliances. Part II: Changes in the blood level of nickel. Am. J. Orthod. Dentofac. 1993, 103, 115-119. [CrossRef]

36. Assad, M.; Lemieux, N.; Rivard, C.H.; Yahia, L.H. Comparative in vitro biocompatibility of nickel-titanium, pure nickel, pure titanium, and stainless steel: Genotoxicity and atomic absorption evaluation. Bio Med. Mater. Eng. 1999, 9, 1-12.

37. Wever, D.J.; Veldhuizen, A.G.; Sanders, M.M.; Schakenraad, J.M.; van Horn, J.R. Cytotoxic, allergic and genotoxic activity of a nickel-titanium alloy. Biomaterials 1997, 18, 1115-1120. [CrossRef]

38. Prymak, O.; Bogdanski, D.; Köller, M.; Esenwein, S.A.; Muhr, G.; Beckmann, F.; Donath, T.; Assad, M.; Epple, M. Morphological characterization and in vitro biocompatibility of a porous nickel-titanium alloy. Biomaterials 2005, 26, 5801-5807. [CrossRef] [PubMed]

39. Liu, X.; Wu, S.; Yeung, K.W.K.; Chan, Y.L.; Hu, T.; Xu, Z.; Liu, X.; Chung, J.C.Y.; Cheung, K.M.C.; Chu, P.K. Relationship between osseointegration and superelastic biomechanics in porous NiTi scaffolds. Biomaterials 2011, 32, 330-338. [CrossRef]

40. Kapanen, A.; Ryhanen, J.; Danilov, A.; Tuukkanen, J. Effect of nickel-titanium shape memory metal alloy on bone formation. Biomaterials 2001, 22, 2475-2480. [CrossRef]

41. Berger-Gorbet, M.; Broxup, B.; Rivard, C.; Yahia, L.H. Biocompatibility testing of NiTi screws using immunohistochemistry on sections containing metallic implants. J. Biomed. Mater. Res. 1996, 32, 243-248. [CrossRef]

42. Zhu, L.; Trepanier, C.; Fino, J.; Pelton, A.R. Oxidation of nitinol and its effect on corrosion resistance. In Proceedings of the ASM Materials \& Processes for Medical Device Conference, Anaheim, CA, USA, 8-10 September 2003; pp. 156-161.

43. Firstov, G.S.; Vitchev, R.G.; Kumar, H.; Blanpain, B.; Van Humbeeck, J. Surface oxidation of NiTi shape memory alloy. Biomaterials 2002, 23, 4863-4871. [CrossRef]

44. Barison, S.; Cattarin, S.; Daolio, S.; Musiani, M.; Tuissi, A. Characterisation of surface oxidation of nickel-titanium alloy by ion-beam and electrochemical techniques. Electrochim. Acta 2004, 50, 11-18. [CrossRef]

45. Kaczmarek, M.; Simka, W.; Baron, A.; Szewczenko, J.; Marciniak, J. Electrochemical behavior of Ni-Ti alloy after surface modification. J. Achiev. Mater. Manuf. Eng. 2006, 18, 111-114.

46. Bakhshi, R.; Darbyshire, A.; Evans, J.E.; You, Z.; Lu, J.; Seifalian, A.M. Polymeric coating of surface modified nitinol stent with POSS-nanocomposite polymer. Colloids Surf. B Biointerfaces 2011, 86, 93-105. [CrossRef]

47. Shabalovskaya, S.A.; Anderegg, J.W. Surface spectroscopic characterization of TiNi nearly equiatomic shape memory alloys for implants. J. Vac. Sci. Technol. 1995, 13, 2624-2632. [CrossRef]

48. Ryhanen, J.; Kallioinen, M.; Tuukkanen, J.; Lehenkari, P.; Junila, J.; Niemela, K.E.; Sandvik, P.; Serlo, W. Bone modelling and cell-material interface response induced by nickel-titanium shape memory alloy after periosteal implantation. Biomaterials 1999, 20, 1309-1317. [CrossRef]

49. Trepanier, C.; Leung, T.K.; Tabrizian, M.; Yahia, H.; Bienvenu, J.G.; Tanguay, J.F.; Piron, D.L.; Bilodeau, L. Preliminary investigation of the effects of surface treatments on biological response to shape memory NiTi stents. J. Biomed. Mater. Res. 1999, 48, 165-171. [CrossRef] 
50. Shabalovskaya, S.A.; Rondelli, G.; Anderegg, J.; Xiong, J.P.; Wu, M. Comparative corrosion performance of black oxide, sandblasted, and fine-drawn nitinol wires in potentiodynamic and potentiostatic tests: Effects of chemical etching and electropolishing. J. Biomed. Mater. Res. 2004, 69, 223-231. [CrossRef]

51. Sevostyanov, M.A.; Fedotov, A.Y.; Kolmakov, A.G.; Zabolotnyi, V.T.; Barinov, S.M.; Goncharenko, B.A.; Komlev, V.S.; Baikin, A.S.; Sergienko, K.V.; Teterina, A.Y.; et al. Mechanical properties of nanostructured nitinol/chitosan composite material. Inorg. Mater. Appl. Res. 2014, 5, 344-346. [CrossRef]

52. Flamini, D.O.; Saugo, M.; Saidman, S.B. Electrodeposition of polypyrrole on Nitinol alloy in the presence of inhibitor ions for corrosion protection. Corros. Sci. 2014, 81, 36-44. [CrossRef]

53. Maho, A.; Delhalle, J.; Mekhalif, Z. Study of the formation process and the characteristics of tantalum layers electrodeposited on nitinol plates in the 1-butyl-1-methylpyrrolidinium bis(trifluoromethylsulfonyl)imide ionic liquid. Electrochim. Acta 2013, 89, 346-358. [CrossRef]

54. Petrović, Z.; Katić, J.; Metikoš-Huković, M.; Dadafarin, H.; Omanovic, S. Modification of a nitinol surface by phosphonate self-assembled monolayers. J. Electrochem. Soc. Phys. Anal. Electrochem. 2011, 158, F159-F165. [CrossRef]

55. Armitage, D.A.; Parker, T.L.; Grant, D.M. Biocompatibility and hemocompatibility of surface-modified NiTi alloys. J. Biomed. Mater. Res. 2003, 66, 129-137. [CrossRef] [PubMed]

56. Nagaoka, A.; Yokoyama, K.; Sakai, J. Evaluation of hydrogen absorption behaviour during acid etching for surface modification of commercial pure Ti, Ti-6Al-4V and Ni-Ti superelastic alloys. Corros. Sci. 2010, 52, 1130-1138. [CrossRef]

57. Shi, P.; Cheng, F.T.; Man, H.C. Improvement in corrosion resistance of NiTi by anodization in acetic acid. Mater. Lett. 2007, 61, 2385-2388. [CrossRef]

58. Devillers, S.; Barthélémy, B.; Fery, I.; Delhalle, J.; Mekhalif, Z. Functionalization of nitinol surface toward a versatile platform for post-grafting chemical reactions. Electrochim. Acta 2011, 56, 8129-8137. [CrossRef]

59. Chu, C.L.; Wang, R.M.; Yin, L.H.; Pu, Y.P.; Lin, P.H.; Dong, Y.S.; Chung, C.Y.; Yeung, K.W.K.; Chu, P.K. Effects of anodic oxidation in $\mathrm{H} 2 \mathrm{SO} 4$ electrolyte on the biocompatibility of NiTi shape memory alloy. Mater. Lett. 2008, 62, 3512-3514. [CrossRef]

60. Wong, M.H.; Cheng, F.T.; Man, H.C. Laser oxidation of NiTi for improving corrosion resistance in Hanks' solution. Mater. Lett. 2007, 61, 3391-3394. [CrossRef]

61. Jamesh, M.I.; Li, P.; Bilek, M.M.M.; Boxman, R.L.; McKenzie, D.R.; Chu, P.K. Evaluation of corrosion resistance and cytocompatibility of graded metal carbon film on Ti and NiTi prepared by hybrid cathodic arc/glow discharge plasma-assisted chemical vapor deposition. Corros. Sci. 2015, 97, 126-138. [CrossRef]

62. Hassel, A.W.; Neelakantan, L.; Zelenkevych, A.; Ruh, A.; Spiegel, M. Selective de-alloying of NiTi by oxochloridation. Corros. Sci. 2008, 50, 1368-1375. [CrossRef]

63. Maho, A.; Kanoufi, F.; Combellas, C.; Delhalle, J.; Mekhalif, Z. Electrochemical investigation of nitinol/tantalum hybrid surfaces modified by alkylphosphonic self-assembled monolayers. Electrochim. Acta 2014, 116, 78-88. [CrossRef]

64. Nasakina, E.O.; Baikin, A.S.; Sevost'yanov, M.A.; Kolmakov, A.G.; Zabolotnyi, V.T.; Solntsev, K.A. Properties of nanostructured titanium nickelide and composite based on it. Theor. Found. Chem. Eng. 2014, 48, 477-486. [CrossRef]

65. Yan, X.; Yang, D.; Liu, X. Electrochemical behavior of YAG laser-welded NiTi shape memory alloy. Trans. Nonferrous Met. Soc. China 2006, 16, 572-576. [CrossRef]

66. Plant, S.D.; Grant, D.M.; Leach, L. Surface modification of NiTi alloy and human platelet activation under static and flow conditions. Mater. Lett. 2007, 61, 2864-2867. [CrossRef]

67. Wong, M.H.; Cheng, F.T.; Man, H.C. In situ hydrothermal synthesis of oxide film on NiTi for improving corrosion resistance in Hanks' solution. Scr. Mater. 2007, 56, 205-208. [CrossRef]

68. Katić, J.; Metikoš-Huković, M.; Škapin, S.D.; Petravić, M.; Varašanec, M. The potential-assisted deposition as valuable tool for producing functional apatite coatings on metallic materials. Electrochim. Acta 2014, 127, 173-179. [CrossRef]

69. Hu, T.; Chu, C.L.; Yin, L.H.; YPPu Dong, Y.S.; Guo, C.; Sheng, X.B.; Chung, J.C.Y.; Chu, P.K. In vitro biocompatibility of titanium-nickel alloy with titanium oxide film by $\mathrm{H} 2 \mathrm{O} 2$ oxidation. Trans. Nonferrous Met. Soc. China 2007, 17, 553-557. [CrossRef] 
70. Chu, C.L.; Hu, T.; Wu, S.L.; Dong, Y.S.; Yin, L.H.; Pu, Y.P.; Lin, P.H.; Chung, C.Y.; Yeung, K.W.K.; Chu, P.K. Surface structure and properties of biomedical NiTi shape memory alloy after Fenton's oxidation. Acta Biomater. 2007, 3, 795-806. [CrossRef]

71. Simka, W.; Kaczmarek, M.; Baron-Wiecheć, A.; Nawrat, G.; Marciniak, J.; Żak, J. Electropolishing and passivation of NiTi shape memory alloy. Electrochim. Acta 2010, 55, 2437-2441. [CrossRef]

72. Thierry, B.; Tabrizian, M.; Savadogo, O.; Yahia, L.H. Effects of sterilization processes on NiTi alloy: Surface characterization. J. Biomed. Mater. Res. 2000, 49, 88-98. [CrossRef]

73. Armitage, D.A.; Grant, D.M. Characterisation of surface-modified nickel titanium alloys. Mater. Sci. Eng. 2003, 349, 89-97. [CrossRef]

74. Nasakina, E.O.; Baikin, A.S.; Sergienko, K.V.; Sevost'yanov, M.A.; Kolmakov, A.G.; Goncharenko, B.A.; Zabolotnyi, V.T.; Fadeev, R.S.; Fadeeva, I.S.; Gudkov, S.V.; et al. Biocompatibility of nanostructured nitinol with titanium or tantalum surface composite layers formed by magnetron sputtering. Dokl. Chem. 2015, 461, 86-88. [CrossRef]

75. Plant, S.D.; Grant, D.M.; Leach, L. Behaviour of human endothelial cells on surface modified NiTi alloy. Biomaterials 2005, 26, 5359-5367. [CrossRef]

76. Jacques, A.; Barthélémy, B.; Delhalle, J.; Mekhalif, Z. Nitinol modified by in situ generated diazonium from its nitro precursor for the SI-ATRP of 2-hydroxyethyl methacrylate. J. Electrochem. Soc. 2015, 162, G94-G102. [CrossRef]

77. Jacques, A.; Devillers, S.; Arrotin, B.; Delhalle, J.; Mekhalif, Z. Polyelectrolyte multilayers deposition on nitinol modified by in situ generated diazonium in gentle conditions. J. Electrochem. Soc. 2014, 161, G55-G62. [CrossRef]

78. Tan, L.; Dodd, R.A.; Crone, W.C. Corrosion and wear-corrosion behavior of NiTi modified by plasma source ion implantation. Biomaterials 2003, 24, 3931-3939. [CrossRef]

79. Nasakina, E.O.; Sevostyanov, M.A.; Golberg, M.A.; Dyomin, K.Y.; Baikin, A.S.; Goncharenko, B.A.; Cherkasov, V.A.; Kolmakov, A.G.; Zabolotnyy, V.T. LongTerm Corrosion Tests of Nanostructural Nitinol of (55.91 wt \% Ni, 44.03 wt \% Ti) Composition under Static Conditions: Composition and Structure before and after Corrosion. Inorg. Mater. Appl. Res. 2015, 6, 53-58. [CrossRef]

80. Eliades, T.; Eliades, G.; Athanasiou, A.E.; Bradley, T.G. Surface characterization of retrieved NiTi orthodontic arcwires. Eur. J. Orthod. 2000, 22, 317-326. [CrossRef] [PubMed]

81. Venugopalan, R.; Trepanier, C. Assessing the corrosion behaviour of Nitinol for minimally-invasive device design. Minim. Invasive Ther. Allied Technol. 2000, 9, 67-74. [CrossRef]

82. Venugopalan, R.; Trepanier, C.; Pelton, A.R.; Lucas, L.C. Comparative electrochemical behavior of NiTi and 316L stainless steel. In Proceedings of the 25th Annual Meeting, Providence, RI, USA, 10-13 May 1999.

83. Trépanier, C.; Gong, X.Y.; Ditter, T.; Pelton, A.; Neely, Y.; Grishaber, R. Effect of wear and crevice on the corrosion resistance of overlapped stents. In Proceedings of the SMST: The International Conference on Shape Memory and Superelastic Technologies, Pacific Grove, CA, USA, 7-11 May 2006; pp. 265-276.

84. Zhuk, N.P. Kurs Korrozii $i$ Zashhity Metallov [The Course of Corrosion and Protection of Metals]; Metallurgy: Moscow, Russia, 1976.

85. Ulig, G.G.; Revi, G.U. Korrozija i Bor'ba s nej. Vvedenie v Korrozionnuju Nauku i Tehniku [Corrosion and Its Prevention]; Chemistry: Leningrad, Russia, 1989.

86. Li, X.; Wang, J.; Han, E.-H.; Ke, W. Influence of fluoride and chloride on corrosion behavior of NiTi orthodontic wires. Acta Biomater. 2007, 3, 807-815. [CrossRef]

87. Shcherbakov, A.I.; Kasatkina, I.V.; Dorofeeva, V.N.; Zalavutdinov, R.K. Ustojchivost' passivnogo sostojanija splava «pamjati» TiNi k pittingovoj korrozii [Passive condition stability of 'memory' alloy TiNi to pitting]. Korroziya: Materialy i Zashchita [Corros. Mater. Prot.] 2007, 12, 6-9.

88. Trépanier, C.; Pelton, A.R. Effect of temperature and $\mathrm{pH}$ on the corrosion resistance of Nitinol. In Proceedings of the ASM Materials and Processes for Medical Devices Conference, Boston, MA, USA, 14-16 November 2005; pp. 392-397.

89. Trépanier, C.; Pelton, A.R. Effect of temperature and $\mathrm{pH}$ on the corrosion resistance of passivated nitinol and stainless steel. In Proceedings of the International Conference on Shape Memory and Superelastic Technologies, Baden-Baden, Germany, 3-7 October 2004; pp. 361-366.

90. Tian, H.; Schryvers, D.; Shabalovskaya, S.; Van Humbeeck, J. Microstructure of surface and subsurface layers of a Ni-Ti shape memory microwire. Microsc. Microanal. 2009, 15, 62-70. [CrossRef] 
91. Mishnaevsky, L., Jr.; Levashov, E.; Valiev, R.Z.; Segurado, J.; Sabirov, I.; Enikeev, N.; Prokoshkin, S.; Solov'yov, A.V.; Korotitskiy, A.; Gutmanas, E.; et al. Nanostructured titanium-based materials for medical implants: Modeling and development. Mater. Sci. Eng. 2014, 81, 1-19. [CrossRef]

92. Nolan, M.; Tofail, S.A.M. Density functional theory simulation of titanium migration and reaction with oxygen in the early stages of oxidation of equiatomic NiTi alloy. Biomaterials 2010, 31, 3439-3448. [CrossRef]

93. Shcherbakov, A.I.; Kasatkina, I.V.; Zalavutdinov, R.K. Ustojchivost' splava «pamjati» TiNi k selektivnoj korrozii [Resistance of 'memory' alloy TiNi to selective corrosion]. Korroziya: Materialy i zashchita [Corros. Mater. Prot.] 2007, 12, 14-16.

94. Amirhanova, N.A.; Valiev, R.Z.; Adasheva, S.L.; Prokof'ev, E.A. Issledovanie korrozionnyh i jelektrohimicheskih svojstv splavov na osnove nikelida titana v krupnozernistom i ul'tramelkozernistom sostojanijah [Investigation of corrosion and electrochemical properties of alloys based on nickel titanium in coarse and ultrafine states]. J. Ufa State Aviat. Tech. Univ. 2006, 7, 143-146.

95. Korotin, D.M.; Bartkowski, S.; Kurmaev, E.Z.; Cholakh, S.O.; Müller, M.; Neumann, M.; Gunderov, D.; Valiev, R.Z.; Cholakh, S.O. Arsenic contamination of coarse-grained and nanostructured nitinol surfaces induced by chemical treatment in hydrofluoric acid. J. Biomed. Mater. Res. 2012, 100, 1812-1816. [CrossRef] [PubMed]

96. Zheng, C.Y.; Nie, F.L.; Zheng, Y.F.; Cheng, Y.; Wei, S.C.; Valiev, R.Z. Enhanced in vitro biocompatibility of ultrafine-grained titanium with hierarchical porous surface. Appl. Surf. Sci. 2011, 257, 5634-5640. [CrossRef]

97. Zheng, C.Y.; Nie, F.L.; Zheng, Y.F.; Cheng, Y.; Wei, S.C.; Ruan, L.; Valiev, R.Z. Enhanced corrosion resistance and cellular behavior of ultrafine-grained biomedical NiTi alloy with a novel SrO-SiO2-TiO2 sol-gel coating. Appl. Surf. Sci. 2011, 257, 5913-5918. [CrossRef]

98. Zhang, X.N. Biomechanical and biocorrosion properties of nanostructured titanium. Adv. Mater. Res. 2007, 29-30, 51-54. [CrossRef]

(C) 2019 by the authors. Licensee MDPI, Basel, Switzerland. This article is an open access article distributed under the terms and conditions of the Creative Commons Attribution (CC BY) license (http://creativecommons.org/licenses/by/4.0/). 